Article

\title{
Evidence for a Carbonatite-Influenced Source Assemblage for Intraplate Basalts from the Buckland Volcanic Province, Queensland, Australia
}

\author{
Joshua J. Shea *(i) and Stephen F. Foley \\ Department Earth and Planetary Sciences and ARC Centre of Excellence for Core to Crust Fluid Systems, \\ Macquarie University, North Ryde 2109, New South Wales, Australia \\ * Correspondence: joshua.shea1@hdr.mq.edu.au
}

Received: 20 June 2019; Accepted: 7 September 2019; Published: 10 September 2019

\begin{abstract}
Eastern Australia contains a widespread suite of primitive ( $\mathrm{MgO} \geq 7.5 \mathrm{wt} . \%)$ intraplate basaltic provinces, including those sited along the longest continental hotspot track on Earth $(\approx 2000 \mathrm{~km}$ ), the Cosgrove track. The Buckland volcanic province is the most southerly basaltic province on the Cosgrove track before a $>1600 \mathrm{~km}$ stretch that contains only sparse leucitite volcanism. Buckland is also situated just northeast of the edge of thick cratonic lithosphere where it transitions to a thinner continental lithosphere $(<110 \mathrm{~km})$ to the east, which may influence the production of plume-derived melts. Here, analysis of minor and trace elements in olivines in alkali basalts and basanites from the Buckland Province are combined with whole-rock compositions to elucidate the mantle source assemblages, and to calibrate minor and trace element indicators in olivine for application to source mineralogy. Olivine xenocrysts show element concentration ranges typical for peridotites; $\mathrm{Mn}$ and $\mathrm{Al}$ concentrations indicate that the ambient mantle is spinel, rather than garnet, peridotite. High modal pyroxene content is indicated by high $\mathrm{Ni}, \mathrm{Zn} / \mathrm{Fe}$, and $\mathrm{Fe} / \mathrm{Mn}$ in olivines, while high Ti/Sc is consistent with amphibole in the source. Residual phlogopite in the source of the basanites is indicated by low $\mathrm{K} / \mathrm{Nb}$ in whole rocks, while apatite contains high $\mathrm{P}_{2} \mathrm{O}_{5}$ and low $\mathrm{Rb} / \mathrm{Sr}(\geq 0.015)$ and $\mathrm{Sr} / \mathrm{La}(\geq 13)$. The basanite source assemblage probably contains apatite, phlogopite, olivine, clinopyroxene and orthopyroxene, whereas the alkali basalt source assemblage is probably amphibole, olivine, orthopyroxene and clinopyroxene \pm phlogopite \pm apatite. Both source assemblages correspond broadly to olivine websterite, with the basanite source lying deeper than that for alkali basalt, explaining the occurrence of phlogopite in the source. This mineralogy, along with whole-rock Ti/Eu, $\mathrm{Zr} / \mathrm{Hf}$ and $\mathrm{P}_{2} \mathrm{O}_{5} / \mathrm{TiO}_{2}$ values approaching those of natural carbonatites, provide evidence showing that the Buckland source consists of a peridotite that has interacted with a carbonate-rich melt whose origin may be in the deep lithosphere or asthenosphere beneath the craton. Similar enrichment processes are probably common throughout eastern Australia, controlling trace element characteristics in basaltic provinces. The topography of the underside of the lithosphere may play a significant role in determining mantle source assemblages by diverting and concentrating melt flow, and thus influence the location of basaltic provinces.
\end{abstract}

Keywords: mantle metasomatism; carbonatite; olivine; trace elements; mantle source; pyroxenite; eastern Australia; intraplate basalts; Buckland

\section{Introduction}

The identification of primitive basalt source assemblages provides a way to understand mantle processes, such as the recycling of crustal material and mantle metasomatism, that are not directly observable on the surface $[1,2]$. Considerable work has been carried out on major and trace elements 
of bulk rocks to identify primary melt compositions and infer mantle source assemblages. However, the source assemblages of many basaltic provinces are still debated, such as the Canary Islands, Baffin Island, West Greenland and intraplate alkali basalts in eastern China [1-8].

Alkaline basic melts in both continental and oceanic environments frequently show a continuous range from alkali basalts through basanites and nephelinites to melilitites [9]. From the 1970s onwards, it was recognised from the trace element compositions of volcanic rock and peridotite xenoliths of southeastern Australia that the origin of the more alkaline members of these series could not be explained without enrichment of the source by mantle metasomatism [10,11]. Furthermore, experiments showed that $\mathrm{H}_{2} \mathrm{O}$ and $\mathrm{CO}_{2}$ in the source were required to explain melilitites [12]. These early models of melt production in a homogeneously metasomatised peridotite source have been replaced by the acceptance that hydrous (and possibly carbonate) minerals are sequestered in separate lithologies rich in amphibole, mica and clinopyroxenes [13], with minor apatite and oxide minerals. It is worthy of note here that eastern Australian volcanics contain xenoliths rich in amphibole and apatite [14,15]. High-pressure experiments investigating the melting of these ultramafic mantle assemblages have shown that melts of amphibole-rich rocks are nephelinitic to basanitic $[16,17]$ because of the high mode of amphibole in the melting reaction and the similarity of amphibole and nephelinite compositions [16]. The mineralogy of the metasomatic assemblages can be explained by the fractionation of basanitic melts at mantle depths [18-20].

Since Sobolev et al. [21], minor and trace elements in olivine have been increasingly used to add resolution to this problem since they capture the earliest information from magmas that enable a primary melt composition to be characterised $[1,22,23]$. This use of minor and trace elements in olivine attributes their concentrations to the modal mineralogy of the source assemblage, which in turn affects the primary melt composition through variations in partition coefficients $\left(\mathrm{D}^{\mathrm{ol} / \mathrm{melt}}\right)$. However, more recent work has shown that pressure, temperature and oxygen fugacity may also change the partitioning behaviour of elements that have been used to distinguish peridotite from pyroxenite sources $[2,5,23,24]$.

Matzen et al. [24] showed that high-Ni olivine phenocrysts are consistent with the high-temperature partial melting of spinel lherzolite followed by low-temperature crystallization of olivine; this provides evidence against an olivine-free mantle assemblage for the Koolau and Mauna Loa tholeiites [21]. However, Herzberg et al. [5] do not agree, arguing that the high-Ni olivines have a distinct pyroxenite signature that high-temperature partial melting and low-temperature olivine crystallisation cannot produce. Yang et al. [2] noted that olivines in basalts derived from metasomatised peridotite and pyroxenite can bear similar indicators, highlighting the need for care if olivine chemistry is to provide further insights into the mineralogy of mantle source assemblages and processes $[2,5,23]$.

There is currently a notable lack of high-quality data for minor and trace elements in olivines from Eastern Australian intraplate basalts. This relatively new geochemical tool has been applied to other off-craton intraplate basalt settings, such as Hawaii, West Greenland, Baffin Island, The Canary Islands and eastern China, but has generally been only poorly calibrated against whole-rock chemistry indicators $[2,5,21,22]$. Here, we combine data for whole-rock and olivine compositions for alkali basalts and basanites from the Buckland volcanic province, Queensland, Australia, to add resolution to well-established indicators for source assemblages and mantle processes based on whole-rock chemistry and to define new olivine indicators. We aim to identify the source assemblages for the Buckland alkali basalts and basanites, shed light on mantle processes and produce a holistic and robust method capable of detecting diverse mantle source assemblages beneath eastern Australia.

\section{Geological Setting}

Eastern Australia hosts one of the world's most extensive intraplate volcanic settings that stretches from northern Queensland to southern Tasmania [25]. Numerous petrological studies have been carried out to distinguish possible mantle source assemblages and metasomatic processes, mainly focusing on whole-rock chemistry, isotopes and xenolith evidence [10,26-28]. Mantle metasomatism has been 
identified in many locations in eastern Australia, and is required to account for magmas enriched in light rare earth elements (LREE) and large ion lithophile elements (LILE), and the presence of minerals, such as amphibole and apatite, in entrained mantle xenoliths [10,11,29-32]. Mantle metasomatism has also been invoked to account for enrichments and unusual variations in trace elements of intraplate basalts and for the presence of amphibole, apatite and mica in xenoliths throughout eastern Australia. These include the Atherton Tablelands (Queensland), Dubbo and the Southern Tablelands (New South Wales), and the Newer Volcanics (Victoria) [27-36]. Yaxley et al. [35] presented evidence from mantle xenoliths from the Newer Volcanic Field in Victoria that suggested a reaction between a carbonate-rich melt and mantle peridotite to produce apatite-bearing wehrlite and lherzolite.

Eastern Australian intraplate basalts comprise over 50 provinces, which were mostly emplaced $<70 \mathrm{Ma}$, with no single geodynamic model explaining all their emplacement mechanisms [29,37]. Central volcanoes are characterised by predominately basaltic flows, which erupted from well-defined vent areas and form large volcanic complexes, together with felsic flows and felsic and mafic intrusions. These provinces form age-progressive tracks running north-south through eastern Australia, for which a plume hypothesis has been invoked [37,38]. Lava fields comprise extensive and often thin lavas that are exclusively basaltic and often contain small amounts of scoria, lava cones and maars. For the Newer Volcanic Field in Victoria, an edge-driven convection model has been proposed [39], although it is unclear if or to what extent mantle plumes may have interacted with edge-driven convection $[38,40]$. Leucitite volcanism in western New South Wales has also been related to plume activity and is defined by small potassium-rich mafic intrusions commonly containing leucite, phlogopite and K-richterite, with rare flows of limited extent and volume.

Davies et al. [38] linked the lithospheric thickness to the distribution of intraplate basalts in eastern Australia, suggesting that lithospheric thickness is a dominant influence over their composition and volume. They showed that basaltic compositions are typically found in regions where the lithosphere is $<110 \mathrm{~km}$ thick, whereas leucitite volcanism occurs in areas of intermediate lithosphere thickness, and no volcanism occurs where the lithosphere is $>150 \mathrm{~km}$. The Buckland Province lies on a transitional zone with a lithosphere thickness $\approx 120 \mathrm{~km}$, with a thin lithosphere to the northeast and thick cratonic lithosphere to the southwest.

Buckland is a central volcano forming the most southerly basaltic province along the Cosgrove track in Queensland, north of a $>1600 \mathrm{~km}$ stretch essentially free of volcanism, which contains only rare leucitite volcanism (Figure 1a). The Buckland lavas erupted between $30.7 \mathrm{Ma} \pm 0.5 \mathrm{Ma}$ and $27.3 \pm 0.8 \mathrm{Ma}$ through the late Paleozoic to early Mesozoic sedimentary Bowen, Galilee, Eromanga and Surat Basins (Figure 1b) [38,41,42]. Two eruption episodes are recognised, the "old" (30.3 Ma $\pm 0.1 \mathrm{Ma})$ and the "young" ( $27.4 \pm 0.2 \mathrm{Ma})$ episode, which were separated by a $\approx 2.5 \mathrm{Myr}$ hiatus with little to no volcanic activity [42,43]. Kennett et al. [44] place the Moho depth underneath Buckland at 38-40 km, and Davies et al. [38] place the lithosphere-asthenosphere boundary (LAB) at $\approx 125 \mathrm{~km}$. 


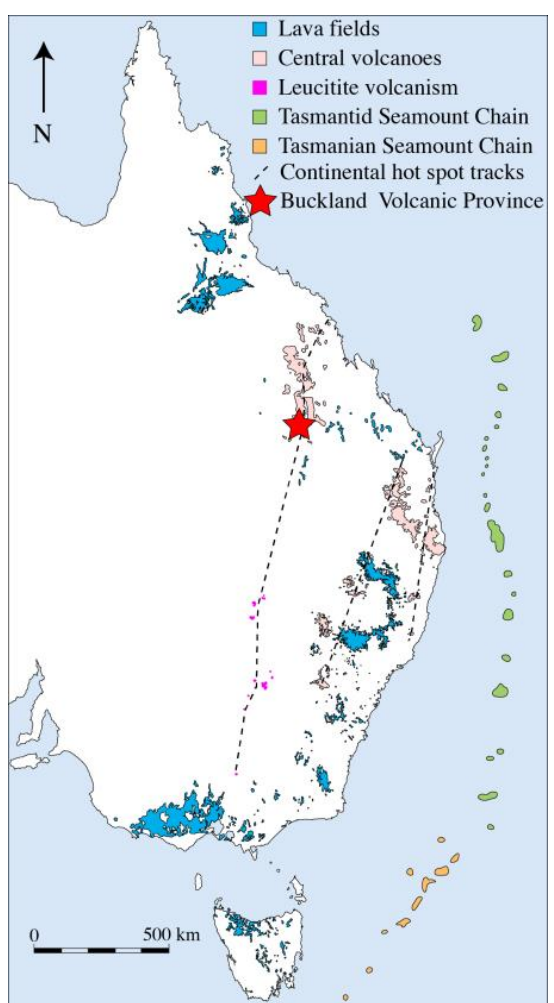

(a)

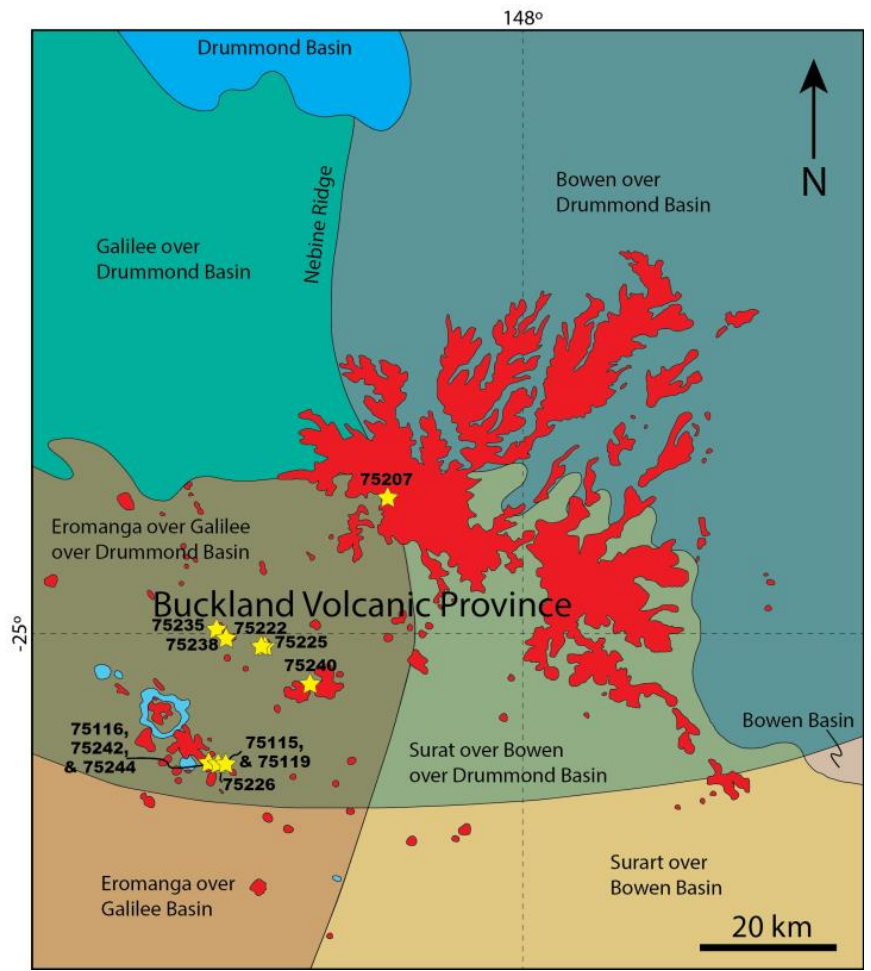

(b)

Figure 1. (a) Locations of late Mesozoic and Cenozoic intraplate volcanic provinces throughout eastern Australia [29,38,45]. The hotspot tracks are from [38], seamount locations are from [45], and Buckland volcanic province is shown by a red star. (b) A close-up of Buckland volcanic province, showing basement domains and locations of samples as yellow stars. Red regions are basaltic material and blue regions are gabbro outcrops, after [41].

Griffin et al. [33] and Skae [46] described xenoliths from Buckland, which provide direct information about the lithospheric mantle. Griffin et al. [33] described two spinel lherzolites and a garnet websterite from Buckland in a large central-east Queensland xenolith dataset. Opx-spinel thermometry yielded temperatures of $900-1050{ }^{\circ} \mathrm{C}$, with an estimated pressure equivalent to $25-50 \mathrm{~km}$ in depth, placing these xenoliths close to the Moho, either in the lowermost crust or the upper lithospheric mantle. Skae [46] collected 14 anhydrous xenoliths from Buckland basanites, where the majority were spinel lherzolites with mineral proportions of olivine $>$ orthopyroxene $>$ clinopyroxene $>$ spinel. The xenoliths from both Skae [46] and Griffin et al. [33] add weight to the suggestion that the primitive basanites were sourced from the spinel lherzolite stability field.

Crossingham et al. [43] provide the most comprehensive genetic study for Buckland and suggest the source assemblage was a garnet-phlogopite-amphibole-bearing peridotite source. They infer the presence of residual phlogopite from negative $\mathrm{K}$ anomalies, which may be due to the interaction of a deep mantle-derived melt with a subcontinental lithospheric mantle. Further, they show there is no petrographic or geochemical evidence for magma mixing and use this to suggest a relatively quick ascent to the surface. They make a case for crustal contamination in the Buckland lavas using coupled increases of $\mathrm{Pb}$ and $\mathrm{K}$ with $\mathrm{Ce} / \mathrm{Pb}, \mathrm{Nb} / \mathrm{U}$ with radiogenic ${ }^{87} \mathrm{Sr} /{ }^{86} \mathrm{Sr}$, and ${ }^{207} \mathrm{~Pb} /{ }^{204} \mathrm{~Pb}$ with less radiogenic ${ }^{143} \mathrm{Nd} /{ }^{144} \mathrm{Nd}$ as time progressed to show higher degrees of crustal contamination in young Buckland lavas than in older lavas.

\section{Analytical Methods}

Samples were selected based on hand sample examination for olivine phenocrysts suitable for laser ablation in primitive basalts; sample locations are given in Figure 1. Selected samples were mostly 
from altitudes ascribed to old Buckland lavas, with a single sample $(75,240)$ at altitudes ascribed to young Buckland [42,43]; altitudes for each sample are given in Supplementary Table S2.

\subsection{Whole-Rock Geochemistry}

Whole-rock sample fractions were powdered in a tungsten carbide mill and melted into glass discs for X-ray fluorescence (XRF) analysis. Glass discs were prepared in a platinum crucible with a flux of 12:22 lithium borate:lithium metaborate. Each sample was placed in a rocking furnace for $20 \mathrm{~min}$ at $1050^{\circ} \mathrm{C}$. Analysis was carried out using a PANalytical Axios, Almelo, The Netherlands, wavelength dispersive $1 \mathrm{~kW}$ (WD) XRF at Macquarie GeoAnalytical, using the United States Geological Survey (USGS) Hawaiian Basalt BHVO-2 as a reference material. Volatile contents were determined via loss on ignition at $1100^{\circ} \mathrm{C}$.

Whole-rock digestions for solution ICP-MS analysis were prepared using the following method: $0.1 \mathrm{~g}$ of sample powder was weighed into clean $15 \mathrm{~mL}$ Savillex Teflon beakers and the mass recorded to four decimal places. Samples were digested using a 1:1 mixture of concentrated HF (Merck, Darmstadt, Germany, Suprapur grade) and distilled concentrated $\mathrm{HNO}_{3}$ (Merck, Darmstadt, Germany, Analar grade) at $150{ }^{\circ} \mathrm{C}$ for $24 \mathrm{~h}$, then dried down and repeated. Then, $2 \mathrm{~mL}$ of perchloric acid $\mathrm{HClO}_{4}$ (Merck, Darmstadt, Germany, Suprapur) were added and refluxed at $170{ }^{\circ} \mathrm{C}$. The perchloric acid solution was dried down at $150{ }^{\circ} \mathrm{C}, 170{ }^{\circ} \mathrm{C}$ and $190^{\circ} \mathrm{C}$ to remove any fluorides that may have formed. A few millilitres of $6 \mathrm{~N} \mathrm{HCl}$ was added and dried down at $190^{\circ} \mathrm{C}$ to remove any residual perchloric acid left in the sample. Finally, $6 \mathrm{~N} \mathrm{HNO}_{3}$ was added and heated at $150{ }^{\circ} \mathrm{C}$ for $24 \mathrm{~h}$ but not allowed to fully dry, and then taken up in $10 \mathrm{~mL}$ of $2 \% \mathrm{HNO}_{3}$ and $0.25 \%$ HF. Each sample solution was diluted with up to $100 \mathrm{~mL}$ with $2 \% \mathrm{HNO}_{3}$ and $0.25 \%$ HF. Five millilitres of each sample solution was spiked with $0.02 \mathrm{~mL}$ of a ${ }^{6} \mathrm{Li}, \mathrm{As}, \mathrm{Rh}, \mathrm{In}, \mathrm{Tm}$ and Bi solution to allow for correction of instrument drift during analysis. The spiked samples were run on an Agilent 7500cs quadrupole ICP-MS at Macquarie GeoAnalytical using USGS reference material BCR-2 as the calibration standard. Spiked solutions (1:1000 and 1:5000) of standards BIR-1, BHVO-2, and BCR-2 were run regularly as a check for accuracy and checked against reported values along with blanks of $\mathrm{HNO}_{3}$.

\subsection{Olivine Analyses}

Electron probe micro-analysis (EPMA) was carried out on a CAMECA, Gennevilliers, France, SX100, at Macquarie GeoAnalytical, Department of Earth and Planetary Sciences, Macquarie University. Operating conditions were a $20 \mathrm{kV}$ acceleration voltage, $20 \mathrm{nA}$ electron beam current, and $2 \mu \mathrm{m}$ beam diameter, using long count times for the minor elements $\mathrm{Ni}, \mathrm{Al}$, and $\mathrm{Mn}$ (Table 1). Alteration zones, cracks and inclusions were avoided during EPMA analysis to obtain reliable data and to allow for later laser ablation at the same locations.

Table 1. Wavelength dispersive spectrometer (WDS) analytical conditions for the quantitative analysis of olivine major and minor element compositions using EPMA.

\begin{tabular}{ccccccccc}
\hline Element & $\mathbf{C a}$ & $\mathbf{C r}$ & $\mathbf{S i}$ & $\mathbf{N i}$ & $\mathbf{A l}$ & $\mathbf{M g}$ & $\mathbf{F e}$ & $\mathbf{M n}$ \\
\hline WDS Channel & 1 & 1 & 2 & 3 & 4 & 4 & 5 & 5 \\
WDS Crystal & $\mathrm{TAP}$ & $\mathrm{TAP}$ & $\mathrm{TAP}$ & $\mathrm{TAP}$ & $\mathrm{TAP}$ & $\mathrm{TAP}$ & $\mathrm{TAP}$ & $\mathrm{TAP}$ \\
Line & $\mathrm{K} \alpha$ & $\mathrm{K} \alpha$ & $\mathrm{K} \alpha$ & $\mathrm{K} \alpha$ & $\mathrm{K} \alpha$ & $\mathrm{K} \alpha$ & $\mathrm{K} \alpha$ & $\mathrm{K} \alpha$ \\
Standard & $\mathrm{CaSiO}_{3}$ & $\mathrm{Cr}_{2} \mathrm{O}_{3}$ & $\mathrm{SCO}^{1}$ & $\mathrm{Ni}$ & $\mathrm{Al}_{2} \mathrm{O}_{3}$ & $\mathrm{SCO}^{1}$ & $\mathrm{Fe}_{2} \mathrm{O}_{3}$ & $\mathrm{Mn}_{\text {garnet }}$ \\
Measuring time (s) & 60 & 60 & 60 & 120 & 80 & 40 & 40 & 80 \\
$\begin{array}{c}\text { Detection limit } \\
\text { (ppm) }\end{array}$ & 50 & 50 & 54 & 30 & 90 & 120 & 80 \\
\hline
\end{tabular}

For laser ablation inductively coupled plasma mass spectrometry (LA-ICP-MS), a $193 \mathrm{~nm}$ ArF excimer laser was used with argon as the carrier gas. The isotopes ${ }^{7} \mathrm{Li},{ }^{11} \mathrm{~B},{ }^{23} \mathrm{Na},{ }^{24} \mathrm{Mg},{ }^{26} \mathrm{Mg}$, ${ }^{27} \mathrm{Al},{ }^{29} \mathrm{Si},{ }^{30} \mathrm{Si},{ }^{31} \mathrm{P},{ }^{43} \mathrm{Ca},{ }^{44} \mathrm{Ca},{ }^{45} \mathrm{Sc},{ }^{47} \mathrm{Ti},{ }^{49} \mathrm{Ti},{ }^{51} \mathrm{~V},{ }^{53} \mathrm{Cr},{ }^{55} \mathrm{Mn},{ }^{59} \mathrm{Co},{ }^{60} \mathrm{Ni},{ }^{62} \mathrm{Ni},{ }^{63} \mathrm{Cu},{ }^{66} \mathrm{Zn},{ }^{67} \mathrm{Zn}$, 
${ }^{88} \mathrm{Sr},{ }^{89} \mathrm{Y},{ }^{90} \mathrm{Zr},{ }^{93} \mathrm{Nb},{ }^{135} \mathrm{Ba},{ }^{137} \mathrm{Ba},{ }^{139} \mathrm{La},{ }^{140} \mathrm{Ce},{ }^{157} \mathrm{Gd}$ and ${ }^{172} \mathrm{Yb}$ were monitored using an Agilent, Lexington, MA, USA, 7700cx Quadrupole LA-ICP-MS at Macquarie GeoAnalytical. Background was collected for $120 \mathrm{~s}$, with a 60 -s ablation time for laser shots at $10 \mathrm{~Hz}$ with a fluence of $5 \mathrm{~J} / \mathrm{cm}^{2}$. National Institute of Standards and Technology (NIST) 612 and 610 glasses [47], BCR-2G [48], and San Carlos Olivine [49] were used as reference materials with the recommended GeoReM values from http://georem.mpch-mainz.gwdg.de/start.asp?dataversion $=$ current. ${ }^{29} \mathrm{Si}$ was used as an internal standard. Homogeneous sections of signal were selected to avoid inclusions and fractionation with depth in the laser ablation holes. Data reduction was carried out using the Glitter software package, version 4.0, developed at Macquarie University, Australia [50]. The laser spot size was mostly $85 \mu \mathrm{m}$, and $65 \mu \mathrm{m}$ in very few cases (three in total) for small crystals, or where necessary to avoid cracks, zonation boundaries or iddingsite alterations. A small spot size has been shown to cause element fractionation [51], but this effect should not be relevant for $85-\mu \mathrm{m}$ ablation holes, as indicated by values for NIST 612 analysed as secondary standards falling within 1 SD of GeoRem values (Supplementary Table S1), and all measurements for ${ }^{63} \mathrm{Cu}$ within $1 \mathrm{SD}$ for BCR-2G. Isobaric interferences were considered for ${ }^{45} \mathrm{Sc},{ }^{63} \mathrm{Cu},{ }^{66} \mathrm{Zn}$ and ${ }^{67} \mathrm{Zn}$. The interference of ${ }^{29} \mathrm{Si}^{16} \mathrm{O}$ on ${ }^{45} \mathrm{Sc}$ amounts to about $0.2-0.25 \mathrm{ppm}[52,53]$; the latter value of $0.25 \mathrm{ppm}$ was used here. Correct values for ${ }^{63} \mathrm{Cu}$ were acquired by re-running data reduction using BCR-2G as the external standard to circumvent the problem of ${ }^{23} \mathrm{Na}^{40} \mathrm{Ar}$ interferences from the NIST 612 glass, which contains $14 \mathrm{wt} . \% \mathrm{Na}_{2} \mathrm{O}$ [53]. For zinc, we used the ${ }^{66} \mathrm{Zn}$ isotope in preference to similar results for ${ }^{67} \mathrm{Zn}$ (only $0.5 \%$ difference) due to its higher abundance, and there is little ${ }^{26} \mathrm{Mg}^{40} \mathrm{Ar}$ production in the plasma [52], which could potentially interfere with ${ }^{66} \mathrm{Zn}$.

\section{Results}

\subsection{Whole-Rock Major and Minor Element Compositions}

Whole-rock compositions are given in Supplementary Table S2. Samples were alkali basalts and basanites, as classified on the total alkali versus silica TAS diagram.

The alkali basalts had primitive MgO contents (8.82-10.1 wt.\%), high Ni (185-241 ppm) and moderate to high $\mathrm{Cr}$ concentrations (109-149 ppm), consistent with primitive mantle-derived melts. $\mathrm{Na}_{2} \mathrm{O}(2.92-3.35 \mathrm{wt} . \%)$ was considerably higher than $\mathrm{K}_{2} \mathrm{O}\left(1.22-1.27 \mathrm{wt} . \% ; \mathrm{Na}_{2} \mathrm{O}+\mathrm{K}_{2} \mathrm{O}=4.14-4.62\right)$. $\mathrm{P}_{2} \mathrm{O}_{5}\left(0.37-0.52\right.$ wt.\%) was high compared to $\mathrm{TiO}_{2}$ (1.69-1.77 wt.\%), yielding elevated $\mathrm{P}_{2} \mathrm{O}_{5} / \mathrm{TiO}_{2}$ (0.21-0.31).

The basanites also had primitive MgO contents (9.7-11.7 wt.\%), high Ni (217-300 ppm) and high $\mathrm{Cr}$ (125-289 ppm), consistent with primitive mantle-derived melts. $\mathrm{Na}_{2} \mathrm{O}$ (2.63-5.9 wt.\%) was considerably higher than $\mathrm{K}_{2} \mathrm{O}\left(1.31-2.11\right.$ wt. $\% ; \mathrm{Na}_{2} \mathrm{O}+\mathrm{K}_{2} \mathrm{O}=4.66-8.00$ wt.\%). $\mathrm{P}_{2} \mathrm{O}_{5}(0.92-1.73$ wt.\%) and $\mathrm{TiO}_{2}(1.98-2.60$ wt. $\%)$ contents yielded more elevated $\mathrm{P}_{2} \mathrm{O}_{5} / \mathrm{TiO}_{2}(0.35-0.87)$ than the alkali basalts.

\subsection{Whole-Rock Incompatible Elements}

Primitive mantle-normalised incompatible element patterns are shown in Figure 2. The basanites and alkali basalts both had ocean island basalt (OIB)-like patterns [45]. However, they contained some significant deviations from OIB patterns for $\mathrm{Rb}, \mathrm{Ba}, \mathrm{K}, \mathrm{Pb}, \mathrm{Sr}, \mathrm{Hf}$ and $\mathrm{Ti}$ for both the basanites and alkali basalts. Eastern Australian intraplate basalts had characteristically high large ion lithophile elements (LILEs) and rare earth elements (REEs). The Buckland basanites had significantly higher $\mathrm{Nb} / \mathrm{Yb}$ (41.9-76.5) than OIB values (22.2) [54]. However, $\mathrm{Nb} / \mathrm{Yb}$ values in the alkali basalts (16.4-21.4) were slightly lower than the OIB values but significantly higher than the N-MORB values (0.66) [54]. 

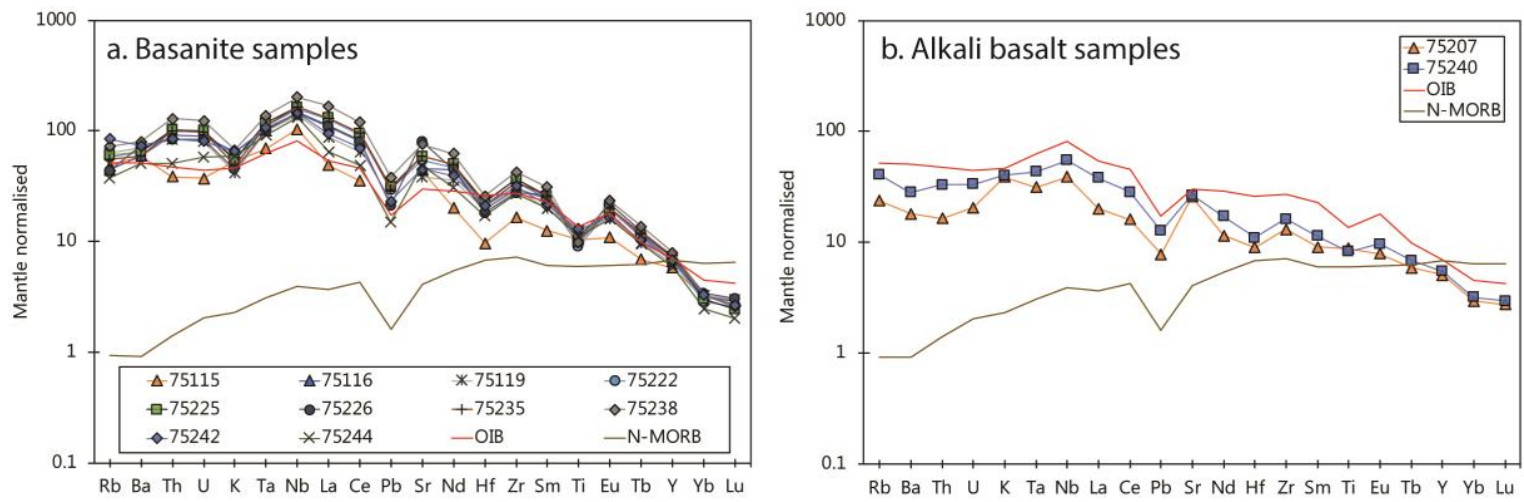

Figure 2. Trace element variation diagrams, normalised to primitive mantle compositions, for the basanites (a) and alkali basalts (b) from the Buckland volcanic province.

\subsection{Olivine Chemistry}

Chemical compositions of more than 100 olivines are given in Supplementary Table S3, and representative analyses are given in Table 2. Olivines had a large range of $\mathrm{Mg} \#((100 \mathrm{Mg} /(\mathrm{Mg}+\mathrm{Fe})$; 73.2-91.3), which was reflected in the large range in the olivine/matrix distribution coefficient for $\mathrm{Mg}$ and $\mathrm{Fe}\left(K_{D, F e-M g}^{o l / m a t r i x}=0.13-0.59\right)$. There were large variations in most minor and trace elements. This included large ranges for indicator elements that had been used to distinguish peridotite from pyroxenite source assemblages: $\mathrm{Ni}(3292-1402 \mathrm{ppm}), \mathrm{Fe} / \mathrm{Mn}(47-87)$ and $(\mathrm{Zn} / \mathrm{Fe}) \times 10^{4}(5.8-18.9)$. There was a noticeable decoupling of $\mathrm{V}$ and Sc concentrations (V 1.01-18.4 ppm and Sc 1.83-7.52 ppm), and large variations in $\mathrm{Ti}$ (1.17-113 ppm), P (21.3-334 ppm), Li (1.63-6.43 ppm) and $\mathrm{Cr}$ (11.9-331 ppm) concentrations.

Table 2. Representative compositions of olivines in alkali basalts and basanites from Buckland. Phenocrysts with $K_{D, F e-M g}^{o l / m a t r i x}<0.27$ were considered in equilibrium with melt, and $\mathrm{Ca}<700 \mathrm{ppm}$, $\mathrm{Ti}<70 \mathrm{ppm}$ and high $\mathrm{Cr}$ concentrations are typical of igneous olivines [23]. All xenocrysts matched the minor and trace element criteria for xenocrysts from Foley et al. [23]. High and low Mg\# xenocryst groups were separated using $K_{D, F e-M g}^{o l / m a t r i x}=0.27$ as a threshold cut-off.

\begin{tabular}{ccccc}
\hline Element/Oxide & $\begin{array}{c}\text { Alkali Basalt } \\
\text { Phenocrysts }\end{array}$ & $\begin{array}{c}\text { Basanite } \\
\text { Phenocrysts }\end{array}$ & $\begin{array}{c}\text { Low Mg\# } \\
\text { Xenocrysts }\end{array}$ & $\begin{array}{c}\text { High Mg\# } \\
\text { Xenocrysts }\end{array}$ \\
\hline $\mathrm{SiO}_{2}($ wt. $\%)$ & 39.37 & 39.00 & 40.19 & 40.94 \\
$\mathrm{Al}_{2} \mathrm{O}_{3}$ & 0.05 & 0.08 & 0.01 & 0.02 \\
$\mathrm{FeO}_{\text {tot }}$ & 15.21 & 17.44 & 12.86 & 9.47 \\
$\mathrm{MnO}$ & 0.21 & 0.22 & 0.18 & 0.14 \\
$\mathrm{MgO}$ & 43.15 & 41.64 & 46.09 & 48.76 \\
$\mathrm{CaO}$ & 0.21 & 0.16 & 0.05 & 0.04 \\
$\mathrm{Cr}_{2} \mathrm{O}_{3}$ & 0.03 & 0.02 & 0.00 & 0.00 \\
$\mathrm{NiO}$ & 0.29 & 0.23 & 0.36 & 0.39 \\
$\mathrm{Total}$ & 98.53 & 98.80 & 99.56 & 99.76 \\
$\mathrm{Mg} \#$ & 83.49 & 80.97 & 86.63 & 90.18 \\
\hline $\mathrm{Li}(\mathrm{ppm})$ & 4.84 & 3.30 & 3.05 & 2.14 \\
$\mathrm{~B}$ & 4.76 & 145 & 3.80 & 5.67 \\
$\mathrm{Na}$ & 94 & 265 & 57 & 41 \\
$\mathrm{Al}$ & 225 & 129 & 64 & 64 \\
$\mathrm{P}$ & 148 & 1058 & 40 & 51 \\
$\mathrm{Ca}$ & 1530 & 4.22 & 244 & 266 \\
$\mathrm{Sc}$ & 5.40 & 95 & 2.45 & 2.74 \\
$\mathrm{Ti}$ & 74 & 7.56 & 16.9 & 14.2 \\
$\mathrm{~V}$ & 8.68 & & 2.37 & 2.40 \\
\hline
\end{tabular}


Table 2. Cont.

\begin{tabular}{ccccc}
\hline Element/Oxide & $\begin{array}{c}\text { Alkali Basalt } \\
\text { Phenocrysts }\end{array}$ & $\begin{array}{c}\text { Basanite } \\
\text { Phenocrysts }\end{array}$ & $\begin{array}{c}\text { Low Mg\# } \\
\text { Xenocrysts }\end{array}$ & $\begin{array}{c}\text { High Mg\# } \\
\text { Xenocrysts }\end{array}$ \\
\hline $\mathrm{Cr}$ & 257 & 105 & 45.4 & 40.5 \\
$\mathrm{Mn}$ & 1790 & 1865 & 1244 & 1188 \\
$\mathrm{Co}$ & 185 & 198 & 152 & 156 \\
$\mathrm{Ni}$ & 2211 & 1796 & 3012 & 3190 \\
$\mathrm{Cu}$ & 1.39 & 1.06 & 1.00 & 1.49 \\
$\mathrm{Zn}$ & 186 & 188 & 111 & 54 \\
$\mathrm{Ga}$ & 0.268 & 0.221 & 0.071 & 0.043 \\
$\mathrm{Sr}$ & 0.051 & 0.078 & 0.264 & 0.022 \\
$\mathrm{Y}$ & 0.156 & 0.118 & 0.028 & $<0.019$ \\
$\mathrm{Zr}$ & 0.097 & 0.097 & $<0.0050$ & $<0.0010$ \\
$\mathrm{Nb}$ & $<0.0095$ & 0.005 & 0.008 & 0.059 \\
$\mathrm{Ba}$ & $<0.0073$ & 0.0069 & $<0.0114$ & $<0.0017$ \\
$\mathrm{La}$ & $<0.0001$ & 0.006 & $<0.0016$ & $<0.0012$ \\
$\mathrm{Ce}$ & $<0.0009$ & $<0.0040$ & $<0.0012$ & $<0.0055$ \\
$\mathrm{Gd}$ & $<0.0067$ & 0.026 & $<0.0091$ & 0.024 \\
$\mathrm{Yb}$ & $0.069 \mathrm{~s}$ & 13.8 & $<0.0080$ & 7.3 \\
$(\mathrm{Zn} / \mathrm{Fe}) \times 10^{4}$ & 15.7 & 80 & 11.3 & 68 \\
$\mathrm{Fe} / \mathrm{Mn}$ & 73 & 1.8 & 71 & 0.9 \\
$\mathrm{~V} / \mathrm{Sc}$ & 1.6 & 12.6 & 1 & 5.9 \\
$\mathrm{Ti} / \mathrm{V}$ & 8.5 & 22.5 & 7.1 & 5.2 \\
$\mathrm{Ti} / \mathrm{Sc}$ & 13.7 & 6.9 & \\
\hline
\end{tabular}

\section{Discussion}

\subsection{Constraints on Igneous Processes in the Buckland Magma Source Region}

No melt segregation pressures have been given for the Buckland magmas, although Ewart [55] estimated segregation pressures for a variety of primitive rocks in eastern Australia: 0.9-1.4 GPa for quartz tholeiites, 0.4-1.6 GPa for olivine tholeiites, 1.6-2.1 GPa for basanites and 2.9-3.1 GPa for nephelinites. These estimates are based on melt compositions in high-pressure experiments, in which alkali basaltic melts are in equilibrium with peridotite at lower pressures than basanitic melts [18,56]. Primitive Buckland basanites have previously been attributed to the melting of a volatile-bearing lherzolite source assemblage with $\mathrm{X}^{\mathrm{H}_{2} \mathrm{O}} \leq 0.2$ and $\mathrm{X}^{\mathrm{H}_{2} \mathrm{O}+\mathrm{CO}_{2}} \leq 0.5 \mathrm{wt}$.\% [46], whereas a source for the alkali basalts has not been constrained. These pressure estimates provide constraints for the stability fields of various minerals that may be present in the source.

Both the alkali basalts' and basanites' whole-rock chemistry from Buckland had unusual fractionations of trace element ratios, particularly $\mathrm{Zr} / \mathrm{Hf}$ and $\mathrm{Ti} / \mathrm{Eu}$ ratios, which were removed from typical OIB values. Similar characteristics have been used to argue for the influence of carbonatite metasomatism in the source region $[32,57,58]$. $\mathrm{Zr} / \mathrm{Hf}$ values of up to 48 are significantly higher than the typical OIB value of 36, and the difference cannot be caused by crystal fractionation because of the primitive compositions of the magmas and the minimal effect of liquidus phases on $\mathrm{Zr} / \mathrm{Hf}[54,57]$. $\mathrm{Zr} / \mathrm{Hf}$ of the alkali basalts $(\approx 50)$ and basanites $(51-58)$ also exceeded primitive mantle values and trended towards the mean $\mathrm{Zr} / \mathrm{Hf}$ values of wehrlite, lherzolite and harzburgite xenoliths from the Newer Volcanic Province in Victoria (>65), for which carbonatite metasomatism of the source has been proposed [32].

High $\mathrm{Zr} / \mathrm{Hf}$ is commonly associated with low Ti/Eu during the process of carbonatite metasomatism. The Buckland alkali basalts had similar Ti/Eu (6267-8059) to primitive mantle (7598), whereas the basanites had a large range (3071-7776), mostly well below primitive mantle and trending towards values observed in natural carbonatites (3-2400 [59]; Figure 3a). This may indicate a greater influence of carbonatite enrichment in the source of the basanites than that of the alkali basalts. The very low degree of melting involved in carbonatite generation from peridotite with $\mathrm{CO}_{2}$ and 
$\mathrm{H}_{2} \mathrm{O}$ imparts very high incompatible trace element concentrations [60,61], causing melts derived from carbonatite-metasomatised domains to be strongly enriched in incompatible elements [62,63], but with these specific signatures for $\mathrm{Zr} / \mathrm{Hf}$ and $\mathrm{Ti} / \mathrm{Eu}[32,57]$.
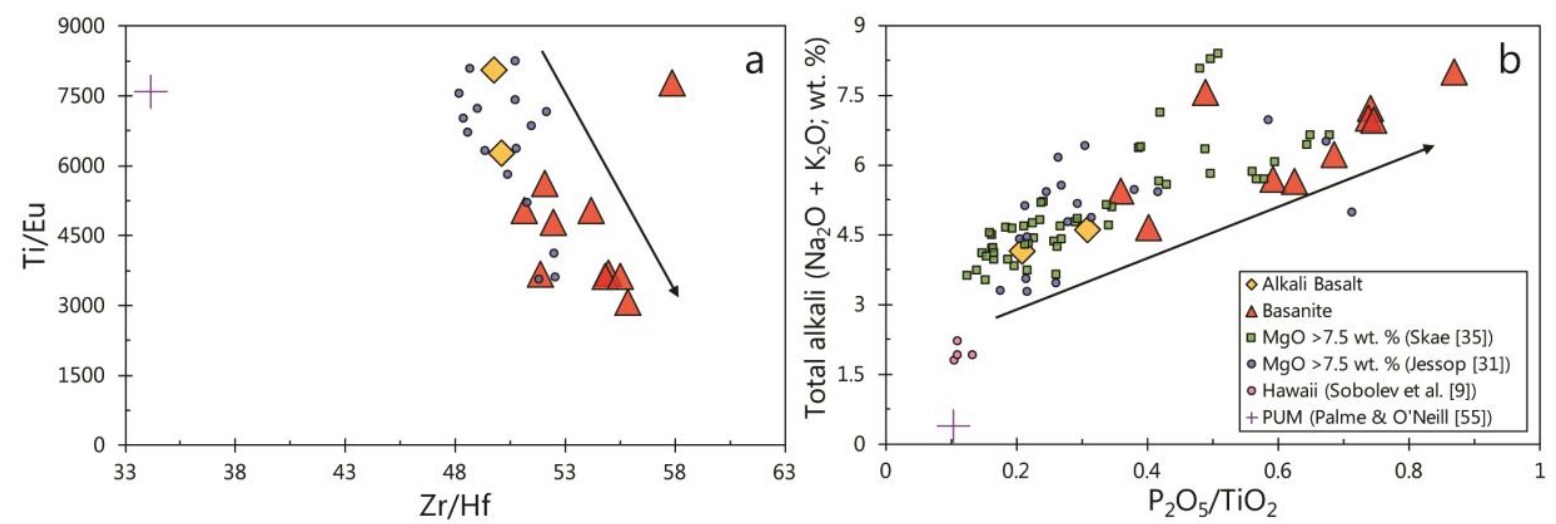

Figure 3. (a) Ti/Eu vs. Zr/Hf plots showing a large removal from the primitive upper mantle (PUM), and stronger carbonatite-like signatures in the Buckland basanites compared to the alkali basalts. (b) Total alkalis plotted against $\mathrm{P}_{2} \mathrm{O}_{5} / \mathrm{TiO}_{2}$ show a correlation with increasing alkali content. Stronger carbonatite-like signatures were removed from values for PUM and Hawaiian tholeiites, indicating that total alkali content in primitive Buckland rocks may be related to carbonatite metasomatism in the source.

The low solubility of Ti minerals, such as rutile and ilmenite, and the relatively high solubility of apatite in carbonate melts makes a high $\mathrm{P}_{2} \mathrm{O}_{5} / \mathrm{TiO}_{2}$ a good indicator for carbonate melt interaction in basaltic source assemblages [64]. Silicate melts generally do not deviate much from primitive mantle values for $\mathrm{P}_{2} \mathrm{O}_{5} / \mathrm{TiO}_{2}(0.1 ;[65])$, whereas carbonatite melts can exhibit extremely high values (up to 16; [64]). Figure $3 \mathrm{~b}$ compares $\mathrm{P}_{2} \mathrm{O}_{5} / \mathrm{TiO}_{2}$ to total alkali contents of the Buckland melts; the basanites showed much higher $\mathrm{P}_{2} \mathrm{O}_{5} / \mathrm{TiO}_{2}$ ratios $(0.36-0.87)$ than the alkali basalts $(0.21-0.31)$ on account of the much higher $\mathrm{P}_{2} \mathrm{O}_{5}$ 0.92-1.53 versus $0.37-0.52 \mathrm{wt}$.\% (Supplementary Table S2). $\mathrm{P}_{2} \mathrm{O}_{5} / \mathrm{TiO}_{2}$ ratios for both were substantially higher than primitive upper mantle (PUM) and Hawaiian tholeiites (average $=0.13$ ) from Sobolev et al. [21], for which, an olivine-free pyroxenite source assemblage produced by the reaction of peridotite with silicate melts has been proposed. The linear increase of $\mathrm{P}_{2} \mathrm{O}_{5} / \mathrm{TiO}_{2}$ with total alkali concentrations in the Buckland melts $\left(\mathrm{R}^{2}=0.70\right)$ suggests that the high $\mathrm{P}_{2} \mathrm{O}_{5} / \mathrm{TiO}_{2}$ values were derived from a combination of alkali-carbonatite melt metasomatism and low degree of melting. High $\mathrm{P}_{2} \mathrm{O}_{5} / \mathrm{TiO}_{2}$ and high total alkali concentrations, coupled with high $\mathrm{Zr} / \mathrm{Hf}$ and low Ti/Eu, were more marked in the Buckland basanites, indicating that their source was more extensively influenced by an alkali-carbonatite metasomatic agent than that of the alkali basalts.

\subsection{Constraints on Source Mineralogy from Whole-Rock Geochemistry}

Potassium shows a slight trough in the trace element pattern for basanites (Figure 2a), indicating that phlogopite may be a residual phase that was also holding back $\mathrm{Rb}$ and $\mathrm{Ba}$ [54]. During partial melting, residual phlogopite produces low $\mathrm{K} / \mathrm{Nb}$ in the extracted melt [36], while silicate melts without residual phlogopite in the source showed $\mathrm{K} / \mathrm{Nb}$ close to primitive mantle values. $\mathrm{K} / \mathrm{Nb}$ in the Buckland alkali basalts ranged from primitive mantle (437; [65]) to lower values (323-437), whereas the basanites (129-221) had values exclusively substantially lower than primitive mantle. The spread of values probably represents the varying importance of residual phlogopite in the source assemblage (the source for sample 75,207 may not contain residual phlogopite), with the basanite source being more influenced by phlogopite than the alkali basalts. Sun and McDonough [54] suggested $\mathrm{Rb} / \mathrm{Cs}$ and $\mathrm{Ba} / \mathrm{Rb}$ as indicators for residual phlogopite, but variations in $\mathrm{Ba}$ and $\mathrm{Rb}$ may also be caused by apatite and amphibole in the source. 
Apatite and amphibole are present as accessory phases in mantle-derived xenoliths from many eastern Australian basaltic provinces $[15,27,29,31,36]$. Phosphorus concentrations were high in the Buckland alkali basalts (1615-2268 ppm) and basanites (4011-7558 ppm) compared to N-MORB (510 ppm; [54]), but only P concentrations of the basanites were higher than OIB values (2700 ppm; [54]). Apatite contributing to the melt can elevate $\mathrm{P}$ and impart low $\mathrm{Sr} / \mathrm{La}, \mathrm{Rb} / \mathrm{La}, \mathrm{K} / \mathrm{U}$ and $\mathrm{K} / \mathrm{Ba}$ values to melts [36]. However, $\mathrm{Rb}, \mathrm{K}$ and $\mathrm{U}$ signatures will also be affected by contributions from residual phlogopite and/or amphibole. Amphiboles in mantle xenoliths from southern Victoria have high $\mathrm{Sr} / \mathrm{La}$ and low $\mathrm{La} / \mathrm{U}$ and have been used to infer contributions from amphibole to basalts in northern Queensland [32,36].

Figure 4 compares and assesses indicators for phlogopite, apatite and amphibole in the source: low $\mathrm{K} / \mathrm{Nb}$ is an indicator for residual phlogopite, whereas $\mathrm{Sr} / \mathrm{La}$ is an indicator for melt contributions from apatite (low values) and amphibole (high values) [36,54]. Most Buckland samples contained low $\mathrm{K} / \mathrm{Nb}$, which was probably the result of widespread phlogopite in the mantle source region for these melts. Most basanites also had low $\mathrm{Sr} / \mathrm{La}$, suggesting residual phlogopite and a melt contribution from apatite. However, some basanites with low $\mathrm{K} / \mathrm{Nb}$ and high $\mathrm{P}_{2} \mathrm{O}_{5}(0.92-1.73 \mathrm{wt} . \%)$ had high $\mathrm{Sr} / \mathrm{La}$ values, suggesting that residual phlogopite and apatite interfered with the $\mathrm{Sr} / \mathrm{La}$ amphibole indicator. The alkali basalt samples contained high $\mathrm{Sr} / \mathrm{La}$ and high $\mathrm{K} / \mathrm{Nb}$ compared to basanites and OIB values, which was probably driven by amphibole contributions to the melt. The combination of low $\mathrm{P}_{2} \mathrm{O}_{5}$ $(0.37-0.52 \mathrm{wt} . \%)$ with high $\mathrm{Sr} / \mathrm{La}$ and high $\mathrm{K} / \mathrm{Nb}$ in the alkali basalts probably rules out significant apatite contribution and residual phlogopite for the alkali basalts.

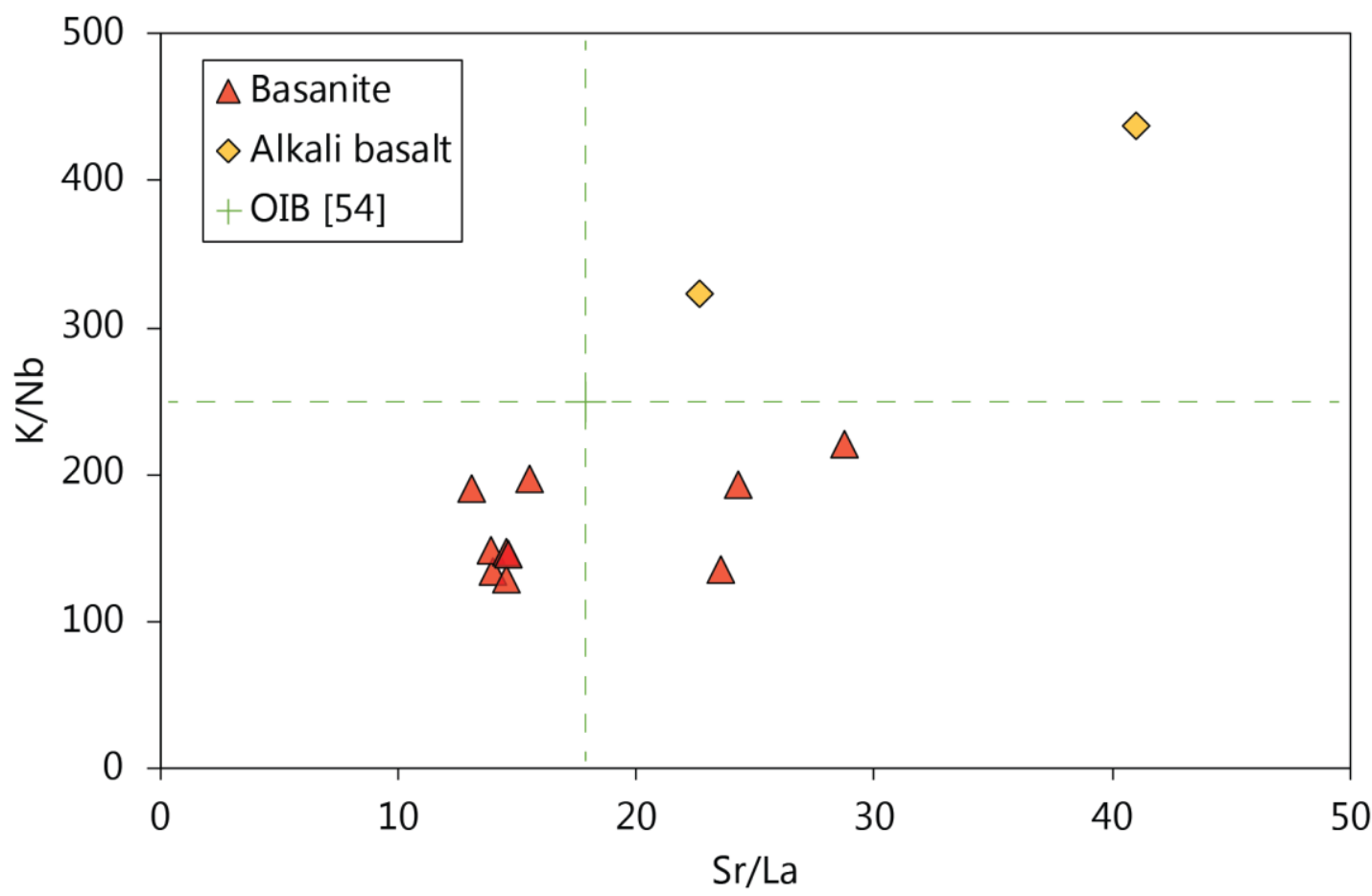

Figure 4. Whole-rock $\mathrm{K} / \mathrm{Nb}$ plotted against $\mathrm{Sr} / \mathrm{La}$ with primitive upper mantle and ocean island basalt compositions. Low $\mathrm{K} / \mathrm{Nb}$ has been used as an indicator for residual phlogopite, while $\mathrm{Sr} / \mathrm{La}$ may indicate apatite (low) or amphibole (high).

In OIB, $\mathrm{Ba}$ and $\mathrm{Cs}$ have large and similar phlogopite/melt $\mathrm{K}_{\mathrm{D}}$ values relative to $\mathrm{Rb}$, resulting in almost constant abundance ratios of $\mathrm{Ba} / \mathrm{Rb} \approx 12$ and $\mathrm{Rb} / \mathrm{Cs} \approx 80$ compared to OIB abundance ratios $(\mathrm{Ba} / \mathrm{Rb}=11 ; \mathrm{Rb} / \mathrm{Cs}=80)$ when residual phlogopite is present in the source [54]. The Buckland basanites had mean abundance ratios for $\mathrm{Ba} / \mathrm{Rb}$ of 75 and $\mathrm{Rb} / \mathrm{Cs}$ of 14 , reinforcing a role for residual phlogopite in the source. In contrast, the alkali basalts had low $\mathrm{Ba} / \mathrm{Rb}$ (8.7-9.7) and a large range of $\mathrm{Rb} / \mathrm{Cs}$ (37-78), which suggests very minor or no residual phlogopite in the alkali basalt source. These signatures 
agree with $\mathrm{K} / \mathrm{Nb}$ signatures for residual phlogopite, with both suggesting residual phlogopite in the basanites and little or no residual phlogopite for the alkali basalts. Although apatite and amphibole contributions to a melt may interfere with $\mathrm{Ba}$ and $\mathrm{Rb}$, they did not appear to eliminate $\mathrm{Ba} / \mathrm{Rb}$ and $\mathrm{Rb} / \mathrm{C}$ s signatures for residual phlogopite in the Buckland basalts, as judged by their similarities to $\mathrm{K} / \mathrm{Nb}$ signatures, which did not have this problem.

Mantle xenoliths containing apatite, amphibole and phlogopite have been collected throughout eastern Australia, notably from the Atherton Tablelands northern Queensland, the southern highlands and Kiama in southeastern New South Wales, the Newer Volcanics in Victoria and Bow Hill in Tasmania [15,28-33,36,66]. Yaxley et al. [32] proposed that the presence of phlogopite, amphibole and apatite in carbonate-bearing spinel wehrlite, lherzolite and harzburgite xenoliths in the Newer Volcanics of Victoria is related to carbonatite metasomatism in the source region. Their model is consistent with carbonatite signatures being the cause of the characteristics of both alkali basalts and basanites at Buckland.

\subsection{Olivine/Melt Equilibrium in the Buckland Rocks}

The recognition of olivines that are in equilibrium with the groundmass of their host rocks can help to discriminate between xenocrysts and phenocrysts, and thus their suitability for use in identifying source assemblages. Intraplate basalts in eastern Australia frequently contain abundant mantle xenoliths [29], which may contaminate basalts when disaggregated during ascent. Basalts often carry high-Mg\# olivine xenocrysts to the surface that are not in equilibrium with the melt.

The following expression from Kesson [26] was used to model the Mg\# of olivine in equilibrium with the alkali basalt and basanite melts from Buckland, with reference to a variety of $K_{D}$ values (Table 3). $\mathrm{Fe}^{2+}$ was used in the $\mathrm{Mg} \#$ calculation for the melt with an approximation of $20 \% \mathrm{Fe}^{2} \mathrm{Fe}^{3+}$, and all Fe in olivine was assumed to be $\mathrm{Fe}^{2+}$.

$$
X_{\text {olivine }}=X_{L} \div\left(X_{L}+K_{D ; F e^{2+-M g}}^{o l / l i q}\left(100-X_{L}\right)\right) \text {, where } X=100 M g /\left(M g+F e^{\prime \prime}\right)
$$

A $K_{D ; F e^{2+}-M g}^{o l / l i q}=0.3$ is typically assumed for tholeiitic basalts, but the Buckland rocks had moderate to high alkali contents $\left(4.14-8.00 \mathrm{wt}\right.$ \%) for which a lower $K_{D ; F e^{2+}-M g}^{\text {ol/liq }}$ is suitable [24,67]. Using $K_{D ; F e^{2+}-M g}^{o l / l i q}=0.27$, olivines in the most primitive alkali basalts should have $\mathrm{Mg \#}$ of 88.4 and $\mathrm{Mg \#} \mathrm{of}$ 87.7 in the basanites, suggesting that olivine with a higher $\mathrm{Mg \#}$ may be xenocrysts.

Olivines with $\mathrm{Mg \#}$ up to 91.3 in the basanites would require a $K_{D ; F e^{2+}-M g}^{o l / l i q}=0.17$ for equilibrium, which is unrealistic; this may only be appropriate for strongly alkaline olivine melilitites and nephelinites that have much higher alkali concentrations than the basanites [67] (Table 3). Therefore, olivines with $K_{D ; F e^{2+}-M g}^{o l / l i q} \leq 0.27$ were assumed to be xenocrysts while those $>0.27$ were assumed to be phenocrysts.

Table 3. $K_{D ; F e^{2+}-M g}^{o l / l i q}$ values for a variety of melts with varying total alkali concentrations.

\begin{tabular}{ccc}
\hline $\boldsymbol{K}_{\boldsymbol{D} ; \boldsymbol{F} \boldsymbol{e}^{2+}-M g}^{\text {l/liq }}$ & Alkali Basalts & Basanites \\
0.35 & $81.3-84.5$ & $81.3-83.6$ \\
0.30 & $83.6-86.4$ & $83.5-85.6$ \\
0.27 & $85.9-88.4$ & $85.9-87.7$ \\
0.17 & $90.0-91.8$ & $89.9-91.3$ \\
\hline
\end{tabular}

\section{Characterising Olivine Xenocrysts}

Minor and trace elements in olivine are well documented for spinel and garnet peridotite facies $[23,52,68]$. The Buckland olivine xenocrysts plotted clearly in the spinel peridotite field, despite the large range for both $\mathrm{Al}(28-502 \mathrm{ppm})$ and $\mathrm{Mn}$ (1071-1697 ppm) (Figure 5). Ti concentrations of 
Buckland xenocrysts fell in the range 2 to $30 \mathrm{ppm}$, also indicating derivation from the spinel peridotite facies, as Ti contents in garnet peridotites are typically $>30 \mathrm{ppm}$ and garnet-spinel bearing peridotites $<2$ ppm [52].

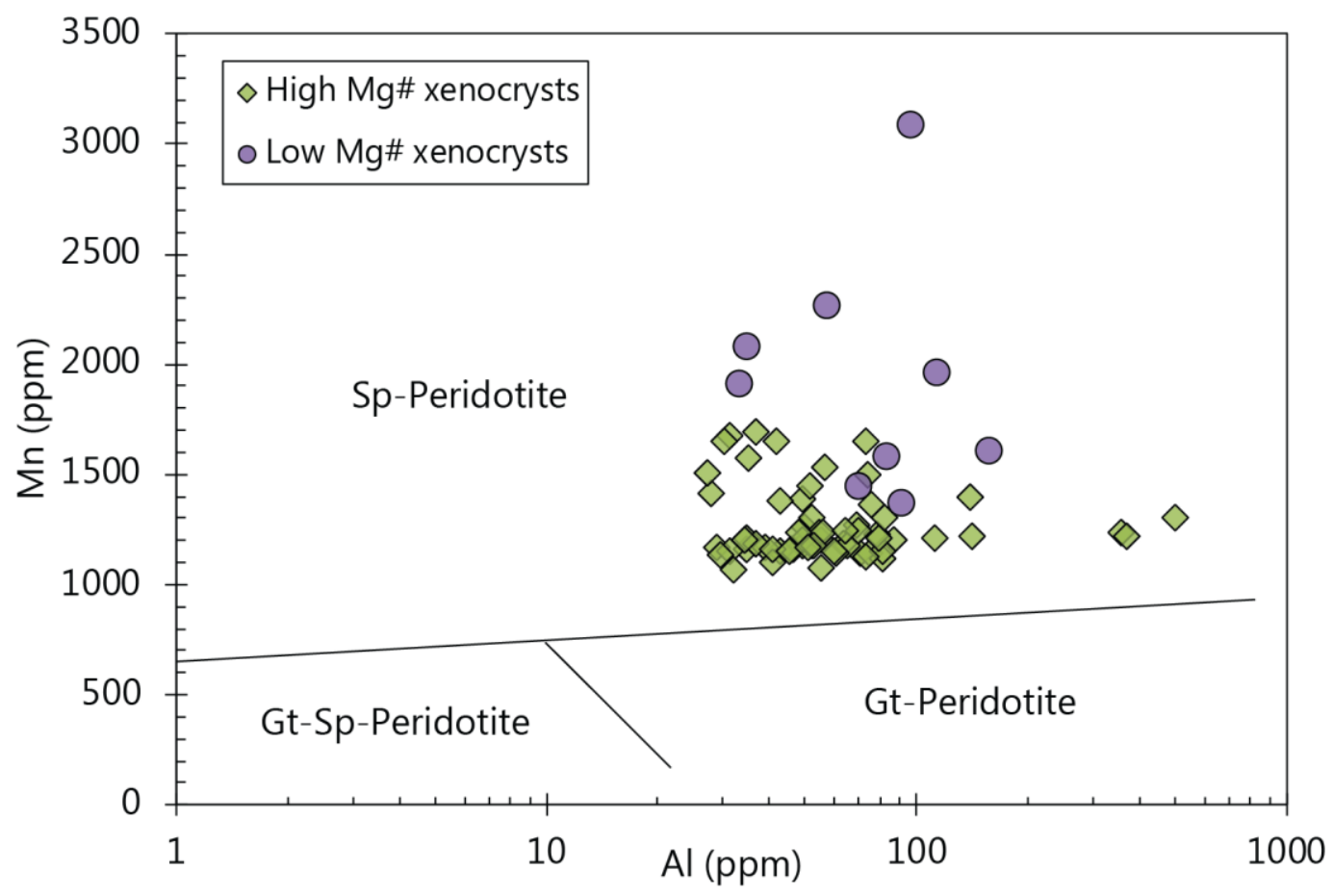

Figure 5. Olivine xenocrysts' Mn plotted against Al, with peridotite field from De Hoog et al. [52]. Both low and high Mg\# xenocrysts plot in the spinel peridotite field, with the large variation in $\mathrm{Mn}$ and $\mathrm{Al}$ concentrations, were likely the result of metasomatism.

Bussweiler et al. [68] compiled a major and minor element scheme for identifying xenocrysts derived from cratonic mantle peridotite: $\mathrm{Mg} \# \geq 90, \mathrm{NiO} \geq 0.3$ wt. $\%$ ( $\geq 2350 \mathrm{ppm}$ ), $\mathrm{MnO} \leq 0.15$ wt. $\%$ ( $\leq 1160 \mathrm{ppm}$ ), and $\mathrm{CaO} \leq 0.1 \mathrm{wt} . \%$ ( $\approx 785 \mathrm{ppm})$; and Foley et al. [23] showed that mantle peridotite xenocrysts typically have $<70 \mathrm{ppm} \mathrm{Ti}, \mathrm{Ni} 2200-3400 \mathrm{ppm}$, and $80 \%$ contain $<130 \mathrm{ppm}$ of Al. The Buckland xenocrysts entire Ni range (2214-3292 ppm) lay within the limits outlined by Foley et al. [23]; only three olivine xenocrysts had Ca $>785 \mathrm{ppm}$, their entire range of Ti (1-64 ppm) lay within the mantle peridotite range, and $96 \%$ contained $\mathrm{Al}<130 \mathrm{ppm}$.

The range of Mg\# for the Buckland xenocrysts was $88.3-91.3$, and only $24 \%$ were $\geq 90$ (24\%), but their minor and trace element criteria agreed with peridotitic criteria. However, mantle metasomatism was expected to lower the Mg\# of peridotitic olivine, which may indicate that the Buckland olivines were xenocrysts from enriched spinel peridotite.

A group of olivines with lower Mg\# (75.7-87.2), but in apparent equilibrium with their groundmass, contained minor and trace element concentrations remarkably similar to the xenocrysts and distinct from those of alkali basalt and basanite phenocrysts. These may be xenocrysts from a mantle domain with Mg\# lowered by mantle metasomatism, or they could be phenocrysts from precursor melts that fractionated within the mantle. These are distinguished as a group referred to as low Mg\# xenocrysts for the remainder of this paper.

Mn concentrations in olivine were $>1200$ ppm for $34 \%$ of Buckland xenocrysts, significantly higher than concentrations suggested for cratonic peridotites [68]. However, spinel lherzolite xenoliths from Boowinda Creek, Carnarvon Gorge in Buckland, had higher MnO concentrations (0.1-0.17 wt.\%; [33,54]) than PUM and other representative upper mantle compositions (KLB-1 MnO = 0.14 wt.\%), showing good overlap between high $\mathrm{MnO}$ xenoliths and high Mn xenocrysts from Buckland. 


\subsection{Constraints on Using Olivine Chemistry as a Source Assemblage Indicator}

The partitioning of minor and trace elements between olivine and melt depends on pressure, temperature, composition and oxygen fugacity $\left(f \mathrm{O}_{2}\right)[23,24,52,69]$. It is therefore necessary to constrain the relevant pressure, temperature and oxygen fugacity conditions in order to infer source conditions. We used the thermometer of Förster et al. [70], which is appropriate for the high alkali concentrations $\left(\mathrm{Na}_{2} \mathrm{O}+\mathrm{K}_{2} \mathrm{O}>3 \mathrm{wt} . \%\right)$ in the Buckland basalts, since this geothermometer uses melt composition $\left(\mathrm{SiO}_{2}, \mathrm{MgO}, \mathrm{FeO}, \mathrm{Na}_{2} \mathrm{O}, \mathrm{K}_{2} \mathrm{O}, \mathrm{TiO}_{2}\right.$ and $\left.\mathrm{K}_{2} \mathrm{O}\right)$ and the partitioning of $\mathrm{Ni}$ between olivine and melt $\left(D_{N i}^{o l / m e l t}\right)$. For this calculation, only melts with olivines in equilibrium with the groundmass were used, and $D_{N i}^{o l / m e l t}$ values were used from olivines with $K_{D ; F e^{2+}-M g}^{o l / l i q} \geq 0.27$, which were considered to be phenocrysts. This yielded values of $1280-1329{ }^{\circ} \mathrm{C}$ for the alkali basalts, and $1289-1388^{\circ} \mathrm{C}$ for the basanites, indicating similar and small ranges of temperature, such that temperature effects on olivine partitioning between the two compositions was negligible. However, the weaker metasomatic signature for alkali-carbonatite in the alkali basalts than in the basanites may indicate a different pressure of origin. This is based on the assumption that a metasomatic agent percolating into the system from below will result in stronger metasomatism at the base of the lithospheric mantle.

The oxygen fugacity of the system can be indicated by V/Sc in olivine since the incorporation of $\mathrm{V}$ into olivine is promoted under reduced conditions [11]. Xenocrysts (both high and low Mg\# groups) have consistently lower V/Sc than alkali basalt and basanite phenocrysts (Figure 6), implying a more oxidised environment of crystallization. However, $\mathrm{V}$ and Sc concentrations in the alkali basalts and basanites may be significantly affected by the presence of amphibole in the source, in a similar way to the effect of phlogopite on the V/Sc ratio of olivine [71]; this is discussed in more detail below. No influence was expected for temperature or $f \mathrm{O}_{2}$ on minor and trace element partitioning into olivine, whereas a pressure effect could not be discounted. All other concentration anomalies were assumed to be characteristic of the source assemblage.

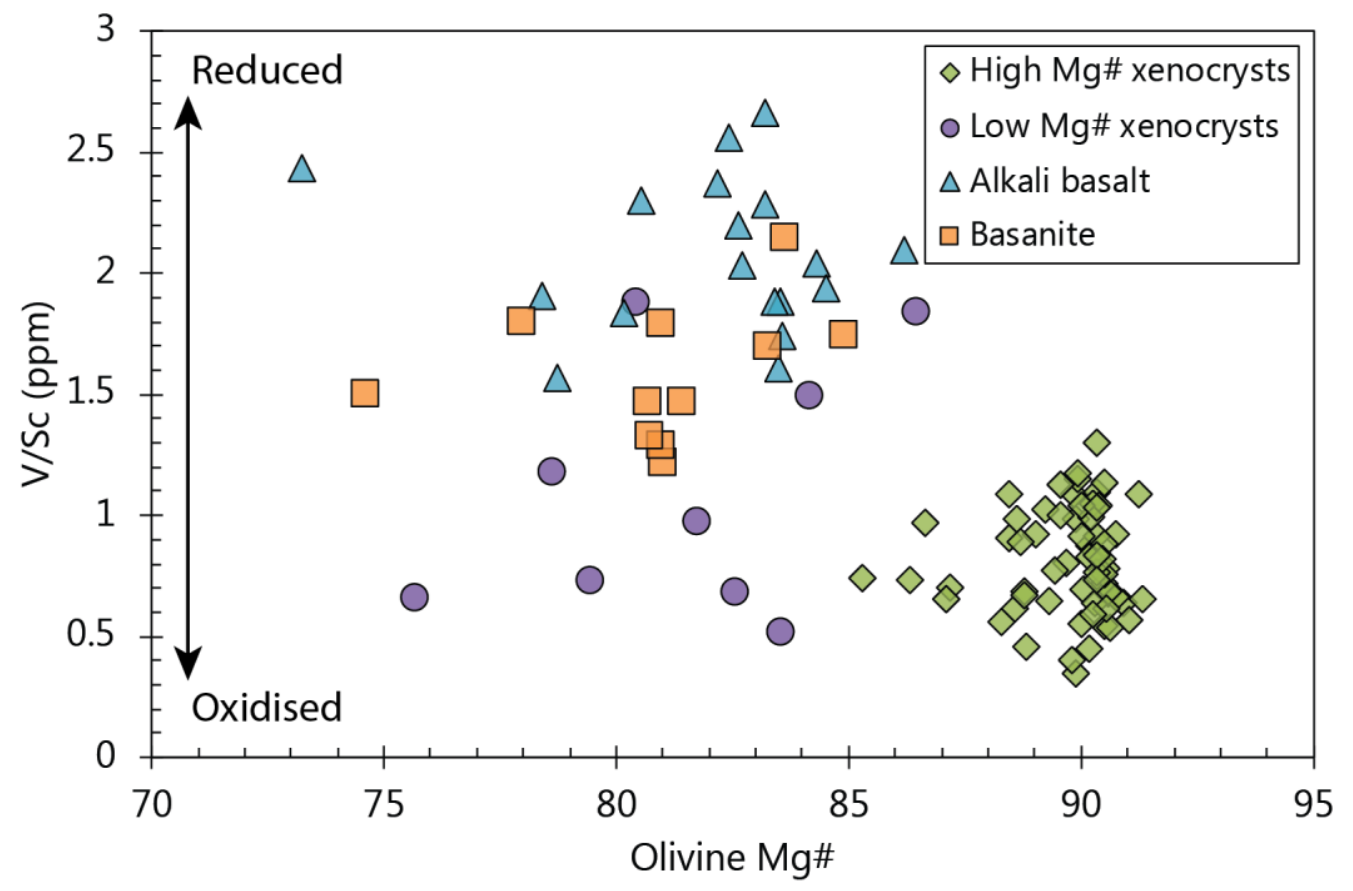

Figure 6. V/Sc plotted against Mg\# of Buckland olivine phenocrysts and xenocrysts. Low V/Sc indicates an oxidised environment, while high values indicate a reduced environment. However, this may be interfered with by minerals such as amphibole and phlogopite in the source assemblages. 


\subsection{Possible Source Indicators from Minor and Trace Elements in Olivine}

\subsubsection{Indicators for a Pyroxene-Rich Source Assemblage}

High $\mathrm{Ni}$ in olivine ( $>3500-4000 \mathrm{ppm}$ for $\mathrm{Mg \#}>90$ ) is commonly used to identify a significant pyroxenite component in the source assemblage. Sobolev et al. [21] used high-Ni olivines in Hawaiian tholeiites to argue that these melts require a substantial proportion of olivine-free pyroxenite in their source. This concept was further propagated by the models of Herzberg [1] and subsequent work. However, the modelling of $\mathrm{Ni}$ and other minor and trace elements in olivine are hampered by the large uncertainties involved, which leaves room for several interpretations. For example, Herzberg et al. [5] showed that $\mathrm{Ni}$ in olivines in basalts related to the West Greenland and Icelandic plumes could be interpreted as being due to $\mathrm{Ni}$ enrichment in the source plume caused by interaction at the core-mantle boundary [72], or by elevated partitioning of Ni into olivine during lithospheric underplating [24]. Furthermore, the effect of alkalis on Ni partitioning complicates interpretations, as $D_{\mathrm{Ni}}^{o l / m e l t}$ in strongly potassic compositions such as lamproites may have extreme $D_{N i}^{o l / m e l t}>50$ [53], substantially higher than primitive tholeiites $\left(D_{\mathrm{Ni}}^{\text {ol } / \text { melt }}=5-10\right)$. Furthermore, Yang et al. [2] suggested caution in using Ni as a source assemblage indicator due to the differences in diffusion rates between $\mathrm{Ni}$ and other elements, such as $\mathrm{Ca}$, that have been used together to infer a pyroxenite source. Many geodynamic settings are more complex than Hawaii, so multiple indicators should be used to arrive at conclusions about source assemblages.

In Figure 7, models of Ni concentration in olivine assuming a peridotite source are calculated using PRIMELT3 [73]. The Ni concentrations in olivine phenocrysts from both Buckland lava types plotted well above the modelled lines, with a greater deviation at lower Mg\#. These deviations could not be the result of fractionation of other minerals, such as clinopyroxene and plagioclase, as this would require extensive crystallization of clinopyroxene prior to and/or with the crystallization of olivine, which is the liquidus phase in primitive basanites and alkali basalts. Fractionation of mixtures of olivine, clinopyroxene and plagioclase from picritic parent melts for Icelandic basalts were modelled by Herzberg et al. [5,74], who showed that a mixture of $70 \%$ clinopyroxene and $30 \%$ olivine flattens the curves in Figure 7 and could result in olivine phenocrysts with 1800-2800 ppm Ni at Mg\# 87-89. Olivine is the first major phenocryst phase in the Buckland rocks, and is joined later by clinopyroxene, which never dominates the phenocryst population. Co-fractionation of olivine and clinopyroxene may explain some of the alkali basalt olivines, which plotted only marginally above the coloured lines in Figure 7 at Mg\# 82-85, but it could not explain most of the low-Mg\# xenocrysts or phenocryst from both the alkali basalts and basanites. Crossingham et al. [43] showed there is no petrographic or geochemical evidence for magma mixing in the Buckland melts, which rules out this process for producing high-Ni olivines. The Buckland phenocrysts followed a similar progression at lower Mg\# as the Koolau phenocrysts from Hawaii [22], which have been attributed to a pyroxenite olivine-free mantle source assemblage. Buckland olivine phenocrysts were also significantly higher than the olivine liquid line of descent from Figure 6 of Herzberg et al. [5] and the PRIMELT3 modelled lines from whole-rock compositions. Both models in Figure 7 assumed peridotite source assemblages and could not account for high-Ni concentrations in Buckland phenocrysts, instead supporting the argument for a pyroxenite-like source.

A source peridotite that has reacted with an infiltrating alkali-carbonatite melt at 1.5-2.0 GPa, consuming orthopyroxene, clinopyroxene and spinel to produce clinopyroxene, olivine and minor amphibole through a number of primary reactions [32] will cause an initial lherzolite to evolve into an olivine wehrlite or cpx-rich lherzolite assemblage. Secondary reactions involving a carbonatite melt interacting with olivine and clinopyroxene produced during first-stage reactions would produce orthopyroxene and halo-apatite [32], moving the assemblage towards an olivine websterite \pm apatite and \pm amphibole [32]. In the resulting pyroxene-rich assemblage, the control of olivine on the bulk partition coefficient for $\mathrm{Ni}$ was substantially diminished, so that $\mathrm{Ni}$ increased in subsequent melts because of the lower partition coefficients for pyroxenes. However, the presence of some olivine 
produced melts with lower Ni concentrations than the Hawaiian tholeiites but with Ni concentrations that were still elevated compared to melts derived from primitive upper mantle peridotites.

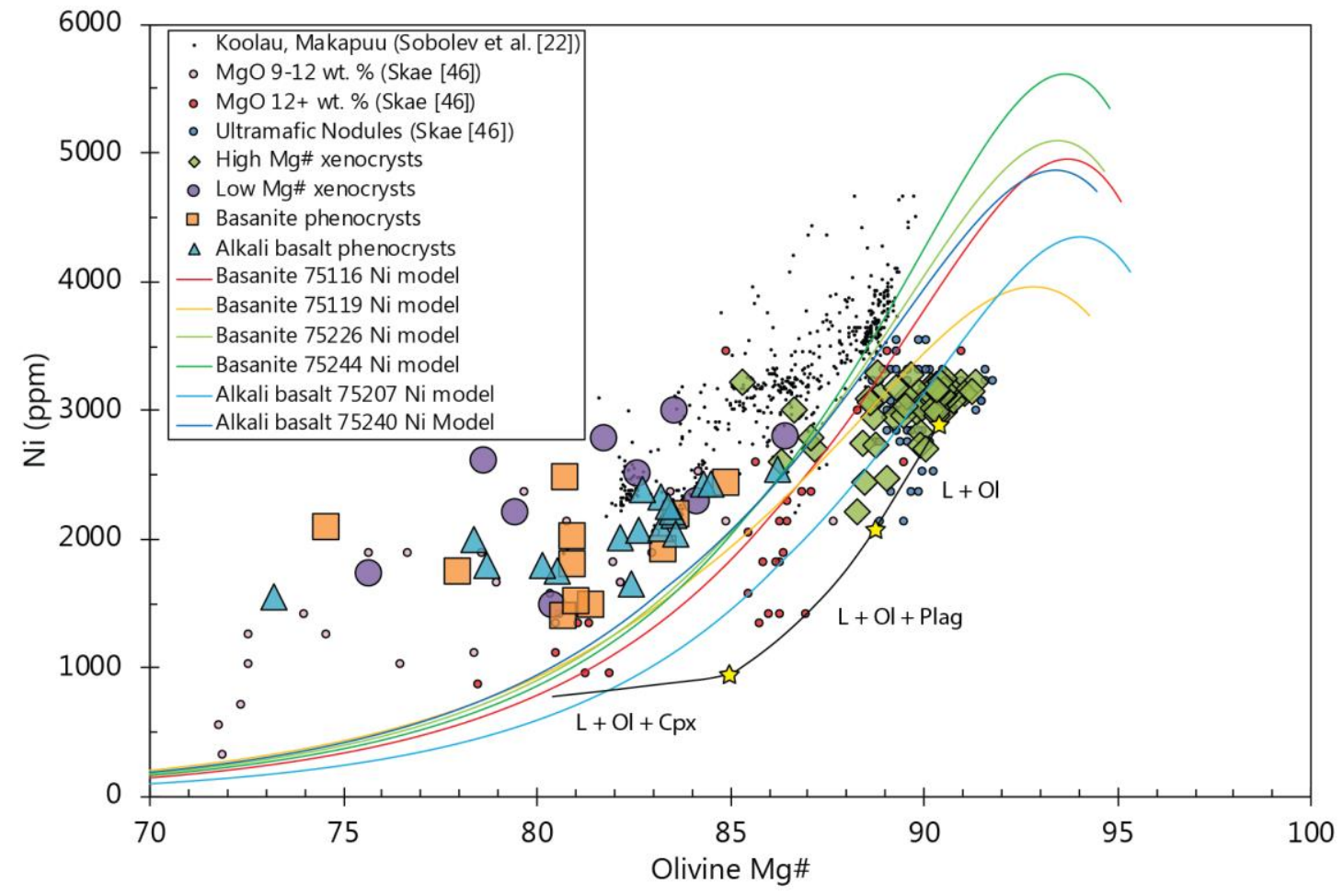

Figure 7. Buckland olivine Ni plotted against Mg\#, where lines are the modelled $\mathrm{Ni}$ and $\mathrm{Mg \#}$ based on the composition of the groundmass, assuming a peridotite source assemblage [73]. The olivine liquid line of descent is from Figure 6 of Herzberg et al. [5], and is based on an upper mantle peridotite source with $0.2 \% \mathrm{H}_{2} \mathrm{O}$. Ni concentrations of the Buckland alkali basalts, basanites and low $\mathrm{Mg \#}$ xenocrysts all plotted above the modelled olivine compositions for a peridotite-derived source.

Low-Ca olivines have been used to identify pyroxenite mantle source assemblages [1] and hydrous mantle sources [75]. However, Ca activity may also be lowered by the elevated $\mathrm{K}_{2} \mathrm{O}$ in a peridotite influenced by alkali-carbonatite [2,76]. Low-Ca olivines in the Buckland rocks had comparable concentrations to low-Ca olivines from the Koolau flow, Hawaii [1,21].

The primitive melt compositions for the Buckland lavas had high $\mathrm{K}_{2} \mathrm{O}$ and low $\mathrm{CaO}$, similar to primary melts derived from metasomatised peridotites [76]. Yang et al. [2] showed that olivines from $\mathrm{K}_{2} \mathrm{O}$-rich (up to $1.5 \mathrm{wt}$.\%) metasomatised peridotite source assemblages produce olivines with low $\mathrm{Ca}$, comparable to concentrations typically assigned to olivines derived from a pyroxenite source assemblage [1]. The Buckland melts contained olivines that were poor in $\mathrm{Ca}$, suggesting that low $\mathrm{Ca}$ activity was a result of the elevated $\mathrm{K}_{2} \mathrm{O}$, and may not be an indicator for a pyroxenite or a hydrous source assemblage.

$\mathrm{Zn} / \mathrm{Fe}$ and $\mathrm{Fe} / \mathrm{Mn}$ in olivine have also been used to indicate a high pyroxene contribution to primary melts $[1,8,22]$. However, metasomatism or an episode of depletion in a melt component can alter these values for a peridotite. The dashed box in Figure 8 indicates the range of values for peridotitic olivine, where the green shaded box shows olivine compositions expected to crystallize from a primary melt from a primitive mantle domain, and the red box shows values for olivines crystallising from a primary melt from a lherzolite estimated to be within $10 \mathrm{~cm}$ of a metasomatised conduit (PHN 1611; [77]). The Buckland olivines had $\mathrm{Zn} / \mathrm{Fe}$ and $\mathrm{Fe} / \mathrm{Mn}$ in the upper part of, or beyond, the range for peridotites; this may indicate that the Buckland source consisted of a mixture of metasomatised peridotite and pyroxenite, which is consistent with the high Ni concentrations in these olivines. 


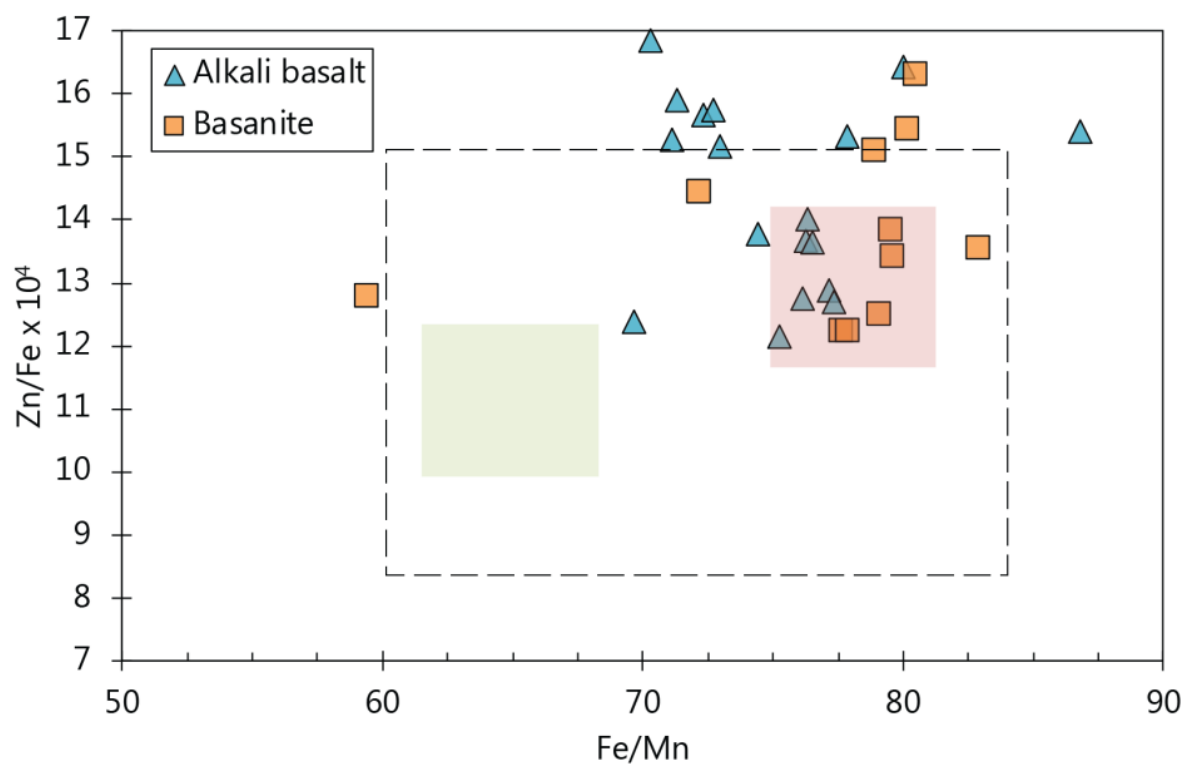

Figure 8. $\mathrm{Zn} / \mathrm{Fe}$ of Buckland olivine phenocrysts plotted against Fe/Mn. Fields are from Yang et al. [2]. The red box indicates olivines crystallised from a melt derived from a sheared lherzolite (PHN 1611) source assemblage [77], the green box represents olivines crystallised in a melt derived from primitive mantle peridotite composition [78], and the dashed box represents olivines from a wide range of peridotite-derived melts [2]; areas outside this dashed box have been interpreted as indicating pyroxenite assemblages. Buckland olivine phenocrysts had high values for both $\mathrm{Zn} / \mathrm{Fe}$ and Fe/Mn, probably indicating the source assemblage was pyroxene-rich and contained olivine.

\subsubsection{Possible Indicators for Clinopyroxene and Amphibole in the Source}

Amphibole may result from the reaction between an infiltrating hydrous carbonatite melt and surrounding peridotite wall rock [32,35]. Amphiboles in eastern Australian ultramafic xenoliths entrained in intraplate basalts are typically pargasites [35] and/or kaersutites [79], and are typical of amphibole compositions in mantle peridotites elsewhere [80]. Table 4 summarizes mineral/silicate melt partitioning behaviour appropriate for upper mantle conditions relevant to the source of the Buckland volcanic province. $\mathrm{Ti}, \mathrm{V}, \mathrm{Sc}, \mathrm{Cr}, \mathrm{Co}, \mathrm{Ni}$ and $\mathrm{Cu}$ are moderately to highly compatible in amphibole $[66,80]$ and the budget of these elements is strongly influenced by amphibole in ultramafic assemblages. Since amphibole is a major contributor to initial melts, controlling their major element compositions [16], melts will be enriched in $\mathrm{Ni}>\mathrm{Cr}>\mathrm{V}>\mathrm{Sc}>\mathrm{Ti}>\mathrm{Co}$. However, due to the relatively low abundance of amphibole in ultramafic xenoliths affected by carbonatite metasomatism, pyroxene probably controls the bulk partitioning of $\mathrm{Ni}$ and $\mathrm{Co}[35,63]$. V, Sc and Ti all diffuse slowly in olivine and vary little with Mg\#, which makes them good candidates for source assemblage indicators [52,81,82]. It should also be noted that $\mathrm{V}$ and Sc may be temperature dependent, but there is only a small temperature difference between the alkali basalts and basanites (see Section 5.1), so this effect is considered negligible for the Buckland olivines. 
Table 4. Partition coefficients between mantle minerals and silicate liquid for phosphorus and first row transition elements. Amphibole partition coefficients are from [66,80]; phosphorus from [66] and apatite from [83]. Clinopyroxene, orthopyroxene and olivine data compiled by [23].

\begin{tabular}{cccccc}
\hline \multirow{2}{*}{ Element } & \multicolumn{5}{c}{ Mineral/Melt Partition Coefficients } \\
\cline { 2 - 5 } & Amphibole & Apatite & Clinopyroxene & Orthopyroxene & Olivine \\
\hline $\mathrm{P}$ & $0.019-0.03$ & & $0.018-0.02$ & 0.007 & $0.038-0.05$ \\
$\mathrm{Sc}$ & $1.62-35$ & 0.22 & 1.40 & 0.64 & 0.23 \\
$\mathrm{Ti}$ & $0.37-18$ & & 0.363 & 0.10 & 0.016 \\
$\mathrm{~V}$ & $1.49-22$ & & 1.3 & 0.80 & 0.09 \\
$\mathrm{Cr}$ & $3.56-53$ & & 3.8 & 5.9 & 0.96 \\
$\mathrm{Mn}$ & & 0.13 & 1.0 & 0.84 & 0.89 \\
$\mathrm{Fe}$ & & & 0.80 & 0.75 & 1.09 \\
$\mathrm{Co}$ & $1.88-2.2$ & $<0.03$ & 1.4 & 1.6 & 3.0 \\
$\mathrm{Ni}$ & $18-32$ & & 2.35 & 2.83 & 10.3 \\
$\mathrm{Cu}$ & $1.1-1.8$ & 0.28 & 0.42 & 0.22 & 0.50 \\
$\mathrm{Zn}$ & $0.33-0.41$ & $<0.25$ & 0.47 & 0.67 & 1.1 \\
\hline
\end{tabular}

Blundy and Dalton [60] suggested that the partitioning behaviour for a carbonated peridotite is a simple relationship between silicate and carbonatite, which depends on the degree of interaction between peridotite and infiltrating carbonatite melts. Clinopyroxene partitioning behaves similarly in silicate and carbonatite melts, apart from Ti and $\mathrm{V}$, which are much more compatible in clinopyroxene in carbonate melts $\left(D_{T i}^{c p x / c a r b}=0.81-2.02\right.$, average $1.4 \pm 0.61 ; D_{V}^{c p x / c a r b}=1.68-3.46$, average $\left.2.89 \pm 0.9 ;[84]\right)$. It is likely that a clinopyroxene-rich carbonated assemblage would increase $\mathrm{Ti}$ and $\mathrm{V}$ partitioning into olivine in derived primary melts [76].

Under oxidised conditions, $\mathrm{V}$ and Sc behave similarly during the melting of peridotite, and so $\mathrm{Ti} / \mathrm{V}$ and Ti/Sc should behave similarly [23,52]. However, a clinopyroxene-rich carbonatite-derived assemblage decouples Ti/V from Ti/Sc because carbonatite metasomatism does not facilitate Sc enrichment in clinopyroxene the same way as Ti and V [84]. The Buckland olivine xenocrysts lie along a 1:1 line, as expected, for the derivation from peridotite (Figure 9).

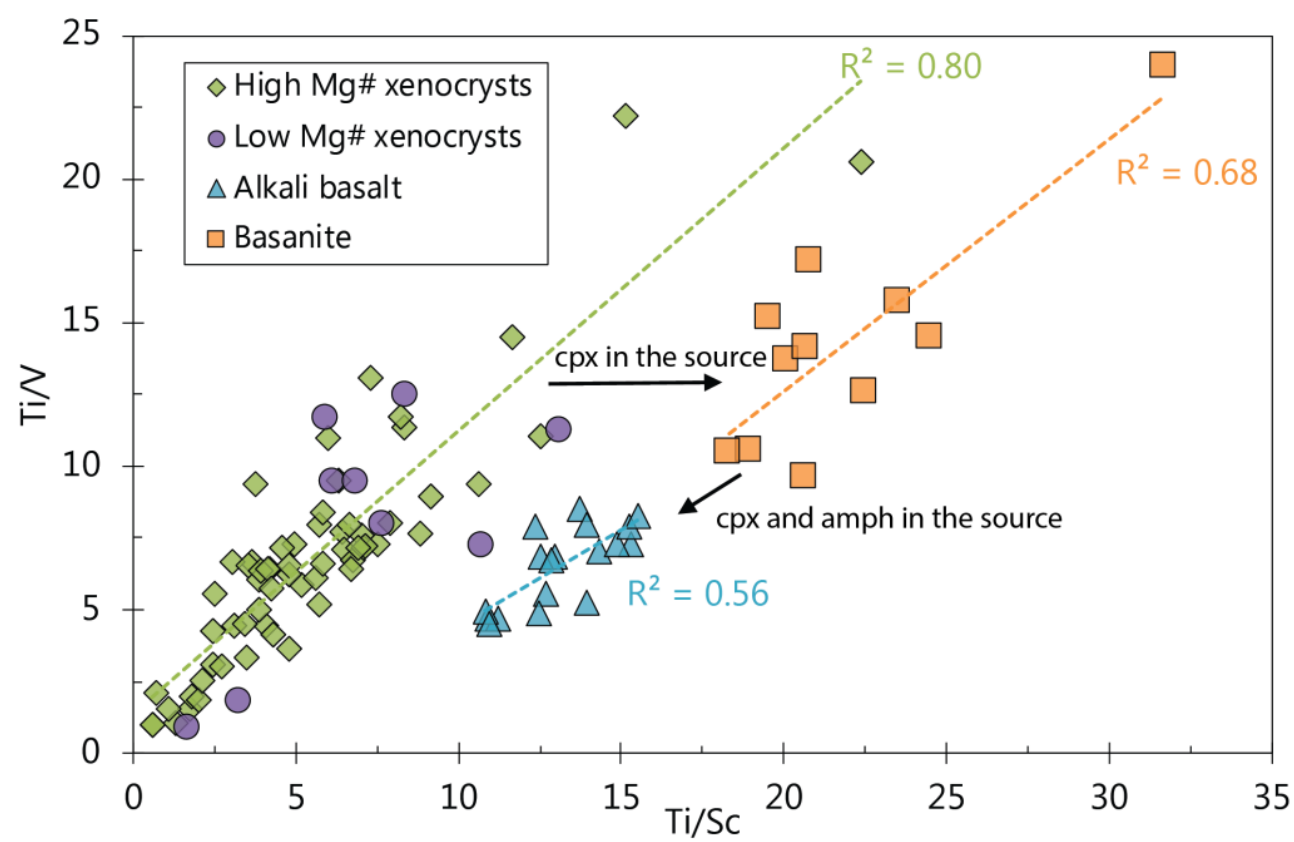

Figure 9. Olivine Ti/V plotted against Ti/Sc. Cpx-clinopyroxene derived from the reaction between mantle peridotite and infiltrating carbonatite melt. Cpx and amph-clinopyroxene and amphibole from the reaction between mantle peridotite and an infiltrating carbonatite melt. 
Olivine phenocrysts typically have higher Ti concentrations than xenocrysts [23], which should place them further along this 1:1 trend if the melts were derived from a purely peridotite source. However, a melt derived from an assemblage with a high modal clinopyroxene formed from carbonatite metasomatism would have Ti and V concentrations that are elevated more than Sc, resulting in high $\mathrm{Ti} / \mathrm{Sc}$ compared to Ti/V. This is exactly what was seen for the Buckland basanite and alkali basalt olivine phenocrysts, which defined a ratio of $\approx 1.4$ instead of 1 (Figure 8 ). The lower Ti/Sc and Ti/V of the alkali basalt phenocrysts relative to the basanite phenocrysts may have been due to amphibole, in which $\mathrm{V}$ and Sc are more compatible than Ti [80]. This means that any amphibole contribution to a melt would result in decreased Ti/V and Ti/Sc in later olivine phenocrysts when compared to a melt without amphibole contribution.

The alkali basalt olivines had similar Ti/V to the olivine xenocrysts, but considerably higher concentrations of both $\mathrm{Ti}$ (average $\mathrm{Ti}=74 \mathrm{vs.} 15.2 \mathrm{ppm}$ in xenocrysts) and $\mathrm{V}$ (12 vs. $2.3 \mathrm{ppm}$ ). The alkali basalt olivines also had significantly higher $\mathrm{V}$ and $\mathrm{Sc}$ than the basanite olivines. The indication of amphibole in the Ti/Sc and Ti/V signature of the alkali basalt olivines aligned with high whole rock $\mathrm{Sr} / \mathrm{La}$, as in amphibole-bearing spinel lherzolites that reacted with carbonatite melts [35].

$\mathrm{Ti}$ and $\mathrm{V}$ could potentially be influenced strongly by Fe-Ti oxide minerals if these are present in the source. Gervasoni et al. [85] found oxide minerals in reaction zones between peridotite and a silicate-carbonate melt at $6 \mathrm{GPa}$, corresponding to metasomatic processes in the deep cratonic lithosphere, but similar experiments involving carbonatite melts at 2.2-2.5 GPa did not produce Fe-Ti oxides. The latter conditions and melt compositions were appropriate for the Buckland source region and corresponded to the reactions in natural peridotites outlined by Yaxley et al. [32].

If oxide minerals were present in the source region, the data for ilmenite/melt and rutile/melt pairs can be used to predict that ilmenite would cause olivine signatures further to the lower right in Figure 9 than is seen in the alkali basalt and basanite phenocrysts [84]. In contrast, the higher $\mathrm{D}_{\mathrm{Ti}}$ than $D_{\mathrm{V}}$ for rutile/melt pairs $[86,87]$ would move the olivines upwards from the 1:1 peridotite source line in Figure 9, which is the opposite direction to that seen in the Buckland phenocrysts. Note that experiments on hydrous pyroxenite show that both these oxide minerals are likely to melt completely and not remain in the residue [16].

\subsubsection{Elevated P and Li Concentrations}

Olivines from the Buckland alkali basalts and basanites have elevated P concentrations (alkali basalts $=74-219 \mathrm{ppm}$ with an average of 127 ; basanites $=36.6-334 \mathrm{ppm}$, with an average of 131), much higher than the high-Mg\# xenocrysts (301-92 ppm), low-Mg\# xenocrysts (37-160) and primitive mantle (87 ppm; [65]). The high P concentrations may be due to the effect of apatite on olivine compositions. However, whole-rock chemistry showed a stronger apatite signature (low $\mathrm{Sr} / \mathrm{La}$ and high $\mathrm{P}_{2} \mathrm{O}_{5}$ ) in the basanites compared to the alkali basalts, which does not agree with higher $\mathrm{P}$ in the basanite olivines.

Li diffuses rapidly in olivine, so care is needed in using it as an indicator [88]. Melts extracted quickly from newly formed or recently metasomatised source assemblages may have elevated $\mathrm{Li}$, which can indicate recycled sedimentary material or mica in the source assemblage [23,89]. However, the lack of Li enrichment does not discount the involvement of recycled crustal material in sources that have been stored in the mantle for extensive periods, as Li may have been lost by diffusion in the intervening period [90,91]. Some Li concentrations in Buckland phenocrysts (2.18-6.46 ppm) were elevated with respect to mantle values ( $<3 \mathrm{ppm}$; [91]), but there was no significant correlation with Zn or Ti that may indicate mica or the input of recycled sediment [23]. This may indicate that there was only minor involvement of recycled crustal material, or that there was a substantial time period between the hydrous-alkali-carbonatite metasomatic event and the subsequent production of the primary melts at Buckland. The elevated $\mathrm{Li}$ in olivine suggests crustal material in the source area rather than crustal contamination during the ascent to the surface [43]. 


\subsection{A Carbonated Peridotite Source Assemblage for the Buckland Volcanic Province}

As a carbonatite melt infiltrates the base of the sub-continental lithosphere and percolates towards the surface, it will react with the surrounding peridotite wall-rock material at 1.5-2.0 GPa, producing a wehrlite to olivine webserite from harzburgite or lherzolite [23,76]. Any significant water content in the carbonatite can produce hydrous phases, such as phlogopite, amphibole or apatite, when reacting with the peridotite [32]. Beneath Buckland, the proportion of peridotite affected by interaction with carbonatite melt probably increased with depth, driving mineral assemblages at the base of the lithosphere towards olivine websterite mineralogy. Later pulses of carbonatite melt may have travelled through coated channels to shallower depths and reacted with shallower peridotite material [13,32]. During later melting of this metasomatised mantle, deeper-derived melts could be expected to possess stronger indications of this metasomatic history.

The minor and trace element chemistry of the olivines coupled with whole-rock geochemical characteristics of the Buckland lavas were consistent with this scenario. Melting at deeper levels favoured melting of the olivine websterite domains in a mixed websterite/peridotite mantle due to the lower solidus temperature of the pyroxene-rich lithologies. This results in olivine phenocrysts with minor and trace element signatures that superficially resembled those thought to be generated following silicate melt metasomatism beneath Hawaii [21]. However, melting of olivine websteritic domains that result from carbonatite/peridotite interaction will retain carbonatite-like Ti/Eu, $\mathrm{Zr} / \mathrm{Hf}$ and $\mathrm{P}_{2} \mathrm{O}_{5} / \mathrm{TiO}_{2}$, as at Buckland, differing from the Hawaiian case. The whole-rock chemistry retained carbonatite-like Ti/Eu, $\mathrm{Zr} / \mathrm{Hf}$ and $\mathrm{P}_{2} \mathrm{O}_{5} / \mathrm{TiO}_{2}$, with weaker carbonatite-like signatures in melts sourced from less metasomatised assemblages (Figure 10). Higher degrees of melting would dilute this signature with peridotite-like signatures. The dilution of pyroxenite/olivine websterite-derived melt by further melting to include peridotite wall-rock material was probably the cause of much of the ambiguity in many high-Ni olivine pyroxenite signatures, such as those found in continental intraplate basalts in eastern China [2].

This process may happen on a large scale underneath the continental crust and may be an important process in the refertilisation of depleted peridotite in the sub-continental lithospheric mantle, in a similar way to the production of pyroxenites by silicate metasomatism [21,92,93]. In eastern Australia, a significant proportion of intraplate volcanism occurs along a $>3000 \mathrm{~km}$ long ledge in the lithosphere base that runs almost parallel to, but 300-400 km west of, the eastern seaboard [38]. This may trigger important cratonic-edge processes that could have caused enhanced interaction between plumes and the sub-lithospheric mantle. This process may enhance trace element indicators that have previously been interpreted as being due to the degree of partial melting of a plume for eastern Australian basalts [38]. Older thicker lithosphere absorbs incipient melts [92]; this may correspond to the source region of the leucitite volcanism in central New South Wales, as well as basaltic provinces on thick lithosphere such as Nandewar [38].

Buckland is located just northeast of this step in the lithosphere thickness; melting below the thicker cratonic lithosphere will be carbonatitic to carbonated silicate in composition [49]. These melts may travel from depth to higher levels east of the step in the base of the lithosphere, impregnating the basaltic province source regions, depositing phlogopite at deeper levels and amphibole at shallower levels. 


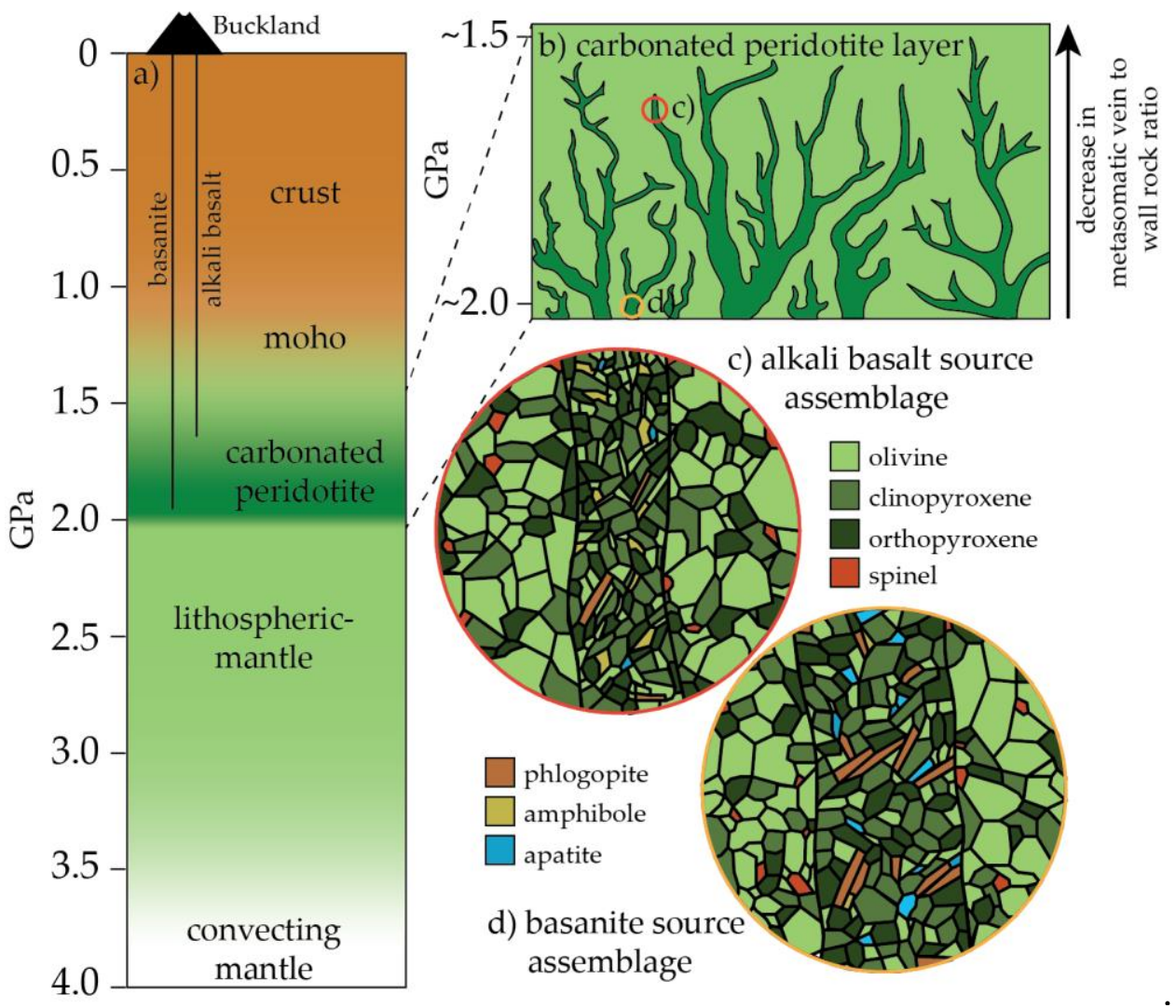

Figure 10. Schematic representation of the source region of the Buckland volcanic province prior to the generation of the alkali basalt and basanite melts, but after the hydrous-alkali-carbonatite metasomatic event. (a) A cross-section of the lithosphere underneath Buckland; LAB depth from [38], and MOHO depth from [44]. (b) Decrease in the degree of metasomatism at shallower depths with source regions circled for alkali basalt (red) and basanites (orange). (c,d) Mineralogy of the peridotite and olivine-websterite domains that contributed to the alkali basalt (c) and the basanite (d) melts.

\section{Conclusions}

- Carbonate-rich melt sourced below the thicker lithosphere to the southwest of the Buckland volcanic province modified the Buckland source to locally produce olivine-websterite lithologies. This may be a widespread process in eastern Australia due to many regional variations in the topography of the lithosphere base.

- Amphibole and clinopyroxene reaction products caused by a carbonatite metasomatic agent reacting with mantle peridotite in the Buckland source region can be recognised in the chemistry of the olivine phenocrysts.

- A combination of olivine compositions and whole-rock geochemistry irons out many uncertainties in interpretations that can arise from using olivine compositions alone.

- High Mg\# olivine xenocrysts are probably derived from xenoliths above the metasomatised horizon.

- Low Mg\# olivine xenocrysts have many minor and trace element signatures that reflect mantle peridotite. They may be formed in an enriched domain where the minor and trace elements have had time to re-equilibrate between sub-solidus phases.

Supplementary Materials: The following are available online at http://www.mdpi.com/2075-163X/9/9/546/s1, Table S1, Laser-ICP-MS measurements made on the reference materials NIST SRM610, SRM 612, BCR-2G and San Carlos Olviine (SCO) as secondary standards, Table S2, Whole rock analyses of Buckland lavas by XRF (major elements; $w \mathrm{t} \%$ ) and (solution) ICP-MS (trace elements; ppm), Table S3, Individual trace element analyses of olivines by Laser-ICP-MS, with major element information by EMPA. 
Author Contributions: This research stems from the MRes thesis work of J.J.S., who carried out the analytical work and prepared the first manuscript draft. S.F.F. assisted with writing, interpretation and editing of the manuscript.

Funding: This research was funded by a Master of Research scholarship to J.J.S. and by the Australian Research Council (ARC) Centre of Excellence for Core to Crust Fluid Systems (CCFS). This is contribution 1349 from the CCFS. SFF is funded by ARC grant FL180100134. The analytical data were obtained using instrumentation funded by DEST systemic infrastructure grants, ARC, LIEF, NCRIS/AuScope, industry partners and Macquarie University.

Acknowledgments: Basalt samples for this study were made available by Kim Jessop, Department of Earth and Planetary Sciences, Sydney, Australia. We thank Yi Jen Lai for assistance with LA-ICP-MS analysis, Tim Murphy for assistance with EPMA analysis. Solution-ICP-MS and XRF analysis was conducted by Peter Wieland.

Conflicts of Interest: The authors declare no conflict of interest.

\section{References}

1. Herzberg, C. Identification of Source Lithology in the Hawaiian and Canary Islands: Implications for Origins. J. Petrol. 2011, 52, 113-146. [CrossRef]

2. Yang, Z.-F.; Li, J.; Liang, W.-F.; Luo, Z.-H. On the chemical markers of pyroxenite contributions in continental basalts in Eastern China: Implications for source lithology and the origin of basalts. Earth Sci. Rev. 2016, 157, 18-31. [CrossRef]

3. Dai, L.-Q.; Zheng, F.; Zhao, Z.-F.; Zheng, Y.-F. Geochemical insights into the lithology of mantle sources for Cenozoic alkali basalts in West Qinling, China. Lithos 2018, 302-303, 86-98. [CrossRef]

4. Heinonen, J.S.; Fusswinkel, T. High Ni and low Mn/Fe in olivine phenocrysts of the Karoo meimechites do not reflect pyroxenitic mantle sources. Chem. Geol. 2017, 467, 134-142. [CrossRef]

5. Herzberg, C.; Vidito, C.; Starkey, N.A. Nickel-cobalt contents of olivine record origins of mantle peridotite and related rocks. Am. Mineral. 2016, 101, 1952-1966. [CrossRef]

6. Howarth, G.H.; Harris, C. Discriminating between pyroxenite and peridotite sources for continental flood basalts (CFB) in southern Africa using olivine chemistry. Earth Planet. Sci. Lett. 2017, 475, 143-151. [CrossRef]

7. Lambart, S.; Laporte, D.; Provost, A.; Schiano, P. Fate of Pyroxenite-derived Melts in the Peridotitic Mantle: Thermodynamic and Experimental Constraints. J. Petrol. 2012, 53, 451-476. [CrossRef]

8. le Roex, A.; Class, C. Metasomatic enrichment of Proterozoic mantle south of the Kaapvaal Craton, South Africa: origin of sinusoidal REE patterns in clinopyroxene and garnet. Contrib. Mineral. Petrol. 2016, 171, 14. [CrossRef]

9. Green, D.H. The origin of basaltic and nephelinitic magmas. Trans. Leic. Philos. Lit. Soc. 1970, 64, 28-54.

10. Frey, F.A.; Green, D.H. The mineralogy, geochemistry and origin of Iherzolite inclusions in Victorian basanites. Geochim. Cosmochim. Acta 1974, 38, 1023-1059. [CrossRef]

11. Frey, F.A.; Green, D.H.; Roy, S.D. Integrated Models of Basalt Petrogenesis: A Study of Quartz Tholeiites to Olivine Melilitites from South Eastern Australia Utilizing Geochemical and Experimental Petrological Data. J. Petrol. 1978, 19, 463-513. [CrossRef]

12. Brey, G. Origin of olivine melilitites-Chemical and experimental constraints. J. Volcanol. Geotherm. Res. 1978, 3, 61-88. [CrossRef]

13. Foley, S. Vein-plus-wall-rock melting mechanisms in the lithosphere and the origin of potassic alkaline magmas. Lithos 1992, 28, 435-453. [CrossRef]

14. Wass, S.Y.; Henderson, P.; Elliott, C.J.; Bailey, D.K.; Tarney, J.; Dunham Kingsley, C. Chemical heterogeneity and metasomatism in the upper mantle: evidence from rare earth and other elements in apatite-rich xenoliths in basaltic rocks from eastern Australia. Philos. Trans. R. Soc. Lond. Ser. A Math. Phys. Sci. 1980, 297, 333-346. [CrossRef]

15. O'Reilly, S.Y.; Griffin, W.L. Apatite in the mantle: implications for metasomatic processes and high heat production in Phanerozoic mantle. Lithos 2000, 53, 217-232. [CrossRef]

16. Foley, S.; Musselwhite, D.; Van der Laan, S. Melt compositions from ultramafic vein assemblages in the lithospheric mantle: a comparison of cratonic and non-cratonic settings. In Proceedings of the VIIth International Kimberlite Conference, Cape Town, South Africa, 11-17 April 1998; pp. 238-246.

17. Pilet, S.; Baker, M.B.; Stolper, E.M. Metasomatized Lithosphere and the Origin of Alkaline Lavas. Science 2008, 320, 916. [CrossRef]

18. Adam, J. The Geochemistry and Experimental Petrology of Sodic Alkaline Basalts from Oatlands, Tasmania. J. Petrol. 1990, 31, 1201-1223. [CrossRef] 
19. Pilet, S.; Baker, M.B.; Müntener, O.; Stolper, E.M. Monte Carlo Simulations of Metasomatic Enrichment in the Lithosphere and Implications for the Source of Alkaline Basalts. J. Petrol. 2011, 52, 1415-1442. [CrossRef]

20. Pilet, S.; Ulmer, P.; Villiger, S. Liquid line of descent of a basanitic liquid at $1.5 \mathrm{GPa}$ : constraints on the formation of metasomatic veins. Contrib. Mineral. Petrol. 2010, 159, 621-643. [CrossRef]

21. Sobolev, A.V.; Hofmann, A.W.; Sobolev, S.V.; Nikogosian, I.K. An olivine-free mantle source of Hawaiian shield basalts. Nature 2005, 434, 590-597. [CrossRef]

22. Sobolev, A.V.; Hofmann, A.W.; Kuzmin, D.V.; Yaxley, G.M.; Arndt, N.T.; Chung, S.-L.; Danyushevsky, L.V.; Elliott, T.; Frey, F.A.; Garcia, M.O.; et al. The Amount of Recycled Crust in Sources of Mantle-Derived Melts. Science 2007, 316, 412. [CrossRef]

23. Foley, S.F.; Prelevic, D.; Rehfeldt, T.; Jacob, D.E. Minor and trace elements in olivines as probes into early igneous and mantle melting processes. Earth Planet. Sci. Lett. 2013, 363, 181-191. [CrossRef]

24. Matzen, A.K.; Baker, M.B.; Beckett, J.R.; Stolper, E.M. The Temperature and Pressure Dependence of Nickel Partitioning between Olivine and Silicate Melt. J. Petrol. 2013, 54, 2521-2545. [CrossRef]

25. Johnson, R.W. Intraplate Volcanism in Eastern Australia and New Zealand; Cambridge University Press: Cambridge, UK, 1989; p. 408.

26. Kesson, S.E. The primary geochemistry of the monaro alkaline volcanics, southeastern Australia-Evidence for upper mantle heterogeneity. Contrib. Mineral. Petrol. 1973, 42, 93-108. [CrossRef]

27. Zhang, M.; O'Reilly, S.Y. Multiple sources for basaltic rocks from Dubbo, eastern Australia: geochemical evidence for plume-Lithospheric mantle interaction. Chem. Geol. 1997, 136, 33-54. [CrossRef]

28. Griffin, W.L.; O'Reilly, S.Y. The lower crust in eastern Australia: xenolith evidence. Geol. Soc. Lond. Spec. Publ. 1986, 24, 363. [CrossRef]

29. O’Reilly, S.Y.; Griffin, W.L. Eastern Australia-4000 kilometres of mantle samples. In Mantle Xenoliths; Nixon, P.H., Ed.; Wiley: Chichester, UK, 1987; pp. 267-280.

30. O’Reilly, S.Y.; Griffin, W.L. Mantle metasomatism beneath western Victoria, Australia: I. Metasomatic processes in Cr-diopside lherzolites. Geochim. Cosmochim. Acta 1988, 52, 433-447. [CrossRef]

31. O'Reilly, S.Y. Volatile-rich mantle beneath eastern Australia. In Mantle Xenoliths; Nixon, P.H., Ed.; Wiley: Chichester, UK, 1987; pp. 661-670.

32. Yaxley, G.M.; Green, D.H.; Kamenetsky, V. Carbonatite Metasomatism in the Southeastern Australian Lithosphere. J. Petrol. 1998, 39, 1917-1930. [CrossRef]

33. Griffin, W.L.; Sutherland, F.L.; Hollis, J.D. Geothermal profile and crust-mantle transition beneath east-central Queensland: Volcanology, xenolith petrology and seismic data. J. Volcanol. Geotherm. Res. 1987, 31, 177-203. [CrossRef]

34. O'Reilly, S.Y.; Zhang, M. Geochemical characteristics of lava-field basalts from eastern Australia and inferred sources: Connections with the subcontinental lithospheric mantle? Contrib. Mineral. Petrol. 1995, 121, 148. [CrossRef]

35. Yaxley, G.M.; Crawford, A.J.; Green, D.H. Evidence for carbonatite metasomatism in spinel peridotite xenoliths from western Victoria, Australia. Earth Planet. Sci. Lett. 1991, 107, 305-317. [CrossRef]

36. Zhang, M.; Stephenson, P.J.; O’Reilly, S.Y.; McCulloch, M.T.; Norman, M. Petrogenesis and Geodynamic Implications of Late Cenozoic Basalts in North Queensland, Australia: Trace-element and $\mathrm{Sr}-\mathrm{Nd}-\mathrm{Pb}$ Isotope Evidence. J. Petrol. 2001, 42, 685-719. [CrossRef]

37. Wellman, P.; McDougall, I. Cainozoic igneous activity in eastern Australia. Tectonophysics 1974, 23, 49-65. [CrossRef]

38. Davies, D.R.; Rawlinson, N.; Iaffaldano, G.; Campbell, I.H. Lithospheric controls on magma composition along Earth's longest continental hotspot track. Nature 2015, 525, 511-514. [CrossRef] [PubMed]

39. Davies, D.R.; Rawlinson, N. On the origin of recent intraplate volcanism in Australia. Geology 2014, 42, 1031-1034. [CrossRef]

40. Demidjuk, Z.; Turner, S.; Sandiford, M.; George, R.; Foden, J.; Etheridge, M. U-series isotope and geodynamic constraints on mantle melting processes beneath the Newer Volcanic Province in South Australia. Earth Planet. Sci. Lett. 2007, 261, 517-533. [CrossRef]

41. Jessop, K. Intrusions, Dykes, Plugs and Flows of the Buckland Tertiary Basalt Province, Central Queensland. Master's Thesis, Macquarie University, North Ryde, Australia, July 2012.

42. Waltenburg, K. Geochronology of Weathered Basaltic Flows at Carnavon Gorge. Bachelor's Thesis, University of Queensland, Brisbane, Australia, November 2006. 
43. Crossingham, T.J.; Ubide, T.; Vasconcelos, P.M.; Knesel, K.M.; Mallmann, G. Temporal constraints on magma generation and differentiation in a continental volcano: Buckland, eastern Australia. Lithos 2018, 302-303, 341-358. [CrossRef]

44. Kennett, B.L.N.; Salmon, M.; Saygin, E.; Group, A.W. AusMoho: The variation of Moho depth in Australia. Geophys. J. Int. 2011, 187, 946-958. [CrossRef]

45. Meeuws, F.J.E.; Holford, S.P.; Foden, J.D.; Schofield, N. Distribution, chronology and causes of Cretaceous-Cenozoic magmatism along the magma-poor rifted southern Australian margin: Links between mantle melting and basin formation. Mar. Pet. Geol. 2016, 73, 271-298. [CrossRef]

46. Skae, A. The Petrology of the Buckland Volcanic Province, Central Queensland, Australia. Ph.D. Thesis, University of Oxford, Oxford, UK, 1998.

47. Jochum, K.P.; Weis, U.; Stoll, B.; Kuzmin, D.; Yang, Q.; Raczek, I.; Jacob, D.E.; Stracke, A.; Birbaum, K.; Frick, D.A.; et al. Determination of Reference Values for NIST SRM 610-617 Glasses Following ISO Guidelines. Geostand. Geoanal. Res. 2011, 35, 397-429. [CrossRef]

48. Jochum, K.P.; Willbold, M.; Raczek, I.; Stoll, B.; Herwig, K. Chemical Characterisation of the USGS Reference Glasses GSA-1G, GSC-1G, GSD-1G, GSE-1G, BCR-2G, BHVO-2G and BIR-1G Using EPMA, ID-TIMS, ID-ICP-MS and LA-ICP-MS. Geostand. Geoanal. Res. 2007, 29, 285-302. [CrossRef]

49. Batanova, V.G.; Sobolev, A.V.; Kuzmin, D.V. Trace element analysis of olivine: High precision analytical method for JEOL JXA-8230 electron probe microanalyser. Chem. Geol. 2015, 419, 149-157. [CrossRef]

50. Griffin, W.L.; Powell, W.; Pearson, N.J.; O’Reilly, S.Y. Glitter: Data reduction software for Laser Ablation ICP-MS. In Laser Ablation-ICP-MS in the Earth Sciences: Current and Outstanding Issues; Sylvester, P., Ed.; Mineralogical Association of Canada: Ottawa, ON, Canada, 2008; Volume 40, pp. 308-311.

51. Bussweiler, Y.; Giuliani, A.; Greig, A.; Kjarsgaard, B.A.; Petts, D.; Jackson, S.E.; Barrett, N.; Luo, Y.; Pearson, D.G. Trace element analysis of high-Mg olivine by LA-ICP-MS-Characterization of natural olivine standards for matrix-matched calibration and application to mantle peridotites. Chem. Geol. 2019, 524, 136-157. [CrossRef]

52. De Hoog, J.C.M.; Gall, L.; Cornell, D.H. Trace-element geochemistry of mantle olivine and application to mantle petrogenesis and geothermobarometry. Chem. Geol. 2010, 270, 196-215. [CrossRef]

53. Foley, S.F.; Jacob, D.E.; O'Neill, H.S.C. Trace element variations in olivine phenocrysts from Ugandan potassic rocks as clues to the chemical characteristics of parental magmas. Contrib. Mineral. Petrol. 2011, 162, 1-20. [CrossRef]

54. Sun, S.; McDonough, W.F. Chemical and isotopic systematics of oceanic basalts: Implications for mantle composition and processes. Geol. Soc. Lond. Spec. Publ. 1989, 42, 313. [CrossRef]

55. Ewart, A. Fractionation, assimilation and source melting: A petrogenetic overview. In Intraplate Volcanism in Eastern Australia and New Zealand; Johnson, R.W., Ed.; Cambridge University Press: Cambridge, UK, 1989; pp. 324-333.

56. Green, D.H. The origin of basaltic and nephelinitic magmas in the earth's mantle. Tectonophysics 1969, 7, 409-422. [CrossRef]

57. Dupuy, C.; Liotard, J.M.; Dostal, J. Zr/Hf fractionation in intraplate basaltic rocks: Carbonate metasomatism in the mantle source. Geochim. Cosmochim. Acta 1992, 56, 2417-2423. [CrossRef]

58. Sweeney, R.J.; Prozesky, V.; Przybylowicz, W. Selected trace and minor element partitioning between peridotite minerals and carbonatite melts at 18-46 kb pressure. Geochim. Cosmochim. Acta 1995, 59, 3671-3683. [CrossRef]

59. Nelson, D.R.; Chivas, A.R.; Chappell, B.W.; McCulloch, M.T. Geochemical and isotopic systematics in carbonatites and implications for the evolution of ocean-island sources. Geochim. Cosmochim. Acta 1988, 52, 1-17. [CrossRef]

60. Blundy, J.; Dalton, J. Experimental comparison of trace element partitioning between clinopyroxene and melt in carbonate and silicate systems, and implications for mantle metasomatism. Contrib. Mineral. Petrol. 2000, 139, 356-371. [CrossRef]

61. Foley, S.F.; Yaxley, G.M.; Rosenthal, A.; Buhre, S.; Kiseeva, E.S.; Rapp, R.P.; Jacob, D.E. The composition of near-solidus melts of peridotite in the presence of $\mathrm{CO}_{2}$ and $\mathrm{H}_{2} \mathrm{O}$ between 40 and 60 kbar. Lithos 2009, 112, 274-283. [CrossRef] 
62. Coltorti, M.; Bonadiman, C.; Hinton, R.W.; Siena, F.; Upton, B.G.J. Carbonatite Metasomatism of the Oceanic Upper Mantle: Evidence from Clinopyroxenes and Glasses in Ultramafic Xenoliths of Grande Comore, Indian Ocean. J. Petrol. 1999, 40, 133-165. [CrossRef]

63. Rudnick, R.L.; McDonough, W.F.; Chappell, B.W. Carbonatite metasomatism in the northern Tanzanian mantle: Petrographic and geochemical characteristics. Earth Planet. Sci. Lett. 1993, 114, 463-475. [CrossRef]

64. Baker, M.B.; Wyllie, P.J. High-pressure apatite solubility in carbonate-rich liquids: Implications for mantle metasomatism. Geochim. Cosmochim. Acta 1992, 56, 3409-3422. [CrossRef]

65. Palme, H.; O’Neill, H.S.C. Cosmochemical Estimates of Mantle Composition. In Treatise on Geochemistry, 2nd ed.; Holland, H.D., Turekian, K.K., Eds.; Elsevier: Oxford, UK, 2014; pp. 1-39.

66. Adam, J.; Green, T. Trace element partitioning between mica- and amphibole-bearing garnet lherzolite and hydrous basanitic melt: 2. Tasmanian Cainozoic basalts and the origins of intraplate basaltic magmas. Contrib. Mineral. Petrol. 2011, 161, 883-899. [CrossRef]

67. Gee, L.L.; Sack, R.O. Experimental Petrology of Melilite Nephelinites. J. Petrol. 1988, 29, 1233-1255. [CrossRef]

68. Bussweiler, Y.; Brey, G.P.; Pearson, D.G.; Stachel, T.; Stern, R.A.; Hardman, M.F.; Kjarsgaard, B.A.; Jackson, S.E. The aluminum-in-olivine thermometer for mantle peridotites-Experimental versus empirical calibration and potential applications. Lithos 2017, 272-273, 301-314. [CrossRef]

69. Taura, H.; Yurimoto, H.; Kurita, K.; Sueno, S. Pressure dependence on partition coefficients for trace elements between olivine and the coexisting melts. Phys. Chem. Miner. 1998, 25, 469-484. [CrossRef]

70. Förster, M.W.; Prelević, D.; Schmück, H.R.; Buhre, S.; Marschall, H.R.; Mertz-Kraus, R.; Jacob, D.E. Melting phlogopite-rich MARID: Lamproites and the role of alkalis in olivine-liquid Ni-partitioning. Chem. Geol. 2018, 476, 429-440. [CrossRef]

71. Veter, M.; Foley, S.F.; Mertz-Kraus, R.; Groschopf, N. Trace elements in olivine of ultramafic lamprophyres controlled by phlogopite-rich mineral assemblages in the mantle source. Lithos 2017, 292-293, 81-95. [CrossRef]

72. Herzberg, C.; Cabral, R.A.; Jackson, M.G.; Vidito, C.; Day, J.M.D.; Hauri, E.H. Phantom Archean crust in Mangaia hotspot lavas and the meaning of heterogeneous mantle. Earth Planet. Sci. Lett. 2014, 396, 97-106. [CrossRef]

73. Herzberg, C.; Asimow, P.D. PRIMELT3 MEGA.XLSM software for primary magma calculation: Peridotite primary magma MgO contents from the liquidus to the solidus. Geochem. Geophys. Geosyst. 2015, 16, 563-578. [CrossRef]

74. Herzberg, C.; Asimow, P.D.; Ionov, D.A.; Vidito, C.; Jackson, M.G.; Geist, D. Nickel and helium evidence for melt above the core-mantle boundary. Nature 2013, 493, 393. [CrossRef] [PubMed]

75. Gavrilenko, M.; Herzberg, C.; Vidito, C.; Carr, M.J.; Tenner, T.; Ozerov, A. A Calcium-in-Olivine Geohygrometer and its Application to Subduction Zone Magmatism. J. Petrol. 2016, 57, 1811-1832. [CrossRef]

76. Davis, F.A.; Hirschmann, M.M. The effects of $\mathrm{K} 2 \mathrm{O}$ on the compositions of near-solidus melts of garnet peridotite at $3 \mathrm{GPa}$ and the origin of basalts from enriched mantle. Contrib. Mineral. Petrol. 2013, 166, 1029-1046. [CrossRef]

77. Smith, D.; Griffin, W.L.; Ryan, C.G. Compositional evolution of high-temperature sheared lherzolite PHN 1611. Geochim. Cosmochim. Acta 1993, 57, 605-613. [CrossRef]

78. McDonough, W.F.; Sun, S.S. The composition of the Earth. Chem. Geol. 1995, 120, 223-253. [CrossRef]

79. Wilkinson, J.F.G. Ultramafic inclusions and high pressure megacrysts from a nephelinite sill, Nandewar Mountains, north-eastern New South Wales, and their bearing on the origin of certain ultramafic inclusions in alkaline volcanic rocks. Contrib. Mineral. Petrol. 1975, 51, 235-262. [CrossRef]

80. Tiepolo, M.; Oberti, R.; Zanetti, A.; Vannucci, R.; Foley, S.F. Trace-Element Partitioning Between Amphibole and Silicate Melt. Rev. Mineral. Geochem. 2007, 67, 417-452. [CrossRef]

81. Cherniak, D.J.; Liang, Y. Titanium diffusion in olivine. Geochim. Cosmochim. Acta 2014, 147, 43-57. [CrossRef]

82. Jollands, M.C.; Hermann, J.; O’Neill, H.S.C.; Spandler, C.; Padrón-Navarta, J.A. Diffusion of Ti and some Divalent Cations in Olivine as a Function of Temperature, Oxygen Fugacity, Chemical Potentials and Crystal Orientation. J. Petrol. 2016, 57, 1983-2010. [CrossRef]

83. Paster, T.P.; Schauwecker, D.S.; Haskin, L.A. The behavior of some trace elements during solidification of the Skaergaard layered series. Geochim. Cosmochim. Acta 1974, 38, 1549-1577. [CrossRef] 
84. Klemme, S.; van der Laan, S.R.; Foley, S.F.; Günther, D. Experimentally determined trace and minor element partitioning between clinopyroxene and carbonatite melt under upper mantle conditions. Earth Planet. Sci. Lett. 1995, 133, 439-448. [CrossRef]

85. Gervasoni, F.; Klemme, S.; Rohrbach, A.; Grützner, T.; Berndt, J. Experimental constraints on mantle metasomatism caused by silicate and carbonate melts. Lithos 2017, 282-283, 173-186. [CrossRef]

86. Foley, S.F.; Barth, M.G.; Jenner, G.A. Rutile/melt partition coefficients for trace elements and an assessment of the influence of rutile on the trace element characteristics of subduction zone magmas. Geochim. Cosmochim. Acta 2000, 64, 933-938. [CrossRef]

87. Klemme, S.; Günther, D.; Hametner, K.; Prowatke, S.; Zack, T. The partitioning of trace elements between ilmenite, ulvospinel, armalcolite and silicate melts with implications for the early differentiation of the moon. Chem. Geol. 2006, 234, 251-263. [CrossRef]

88. Dohmen, R.; Kasemann, S.A.; Coogan, L.; Chakraborty, S. Diffusion of Li in olivine. Part I: Experimental observations and a multi species diffusion model. Geochim. Cosmochim. Acta 2010, 74, 274-292. [CrossRef]

89. Ammannati, E.; Jacob, D.E.; Avanzinelli, R.; Foley, S.F.; Conticelli, S. Low Ni olivine in silica-undersaturated ultrapotassic igneous rocks as evidence for carbonate metasomatism in the mantle. Earth Planet. Sci. Lett. 2016, 444, 64-74. [CrossRef]

90. Jaques, A.L.; Foley, S.F. Insights into the petrogenesis of the West Kimberley lamproites from trace elements in olivine. Mineral. Petrol. 2018, 112, 519-537. [CrossRef]

91. Seitz,H.-M.; Woodland, A.B. The distribution of lithium in peridotitic and pyroxenitic mantle lithologies-An indicator of magmatic and metasomatic processes. Chem. Geol. 2000, 166, 47-64. [CrossRef]

92. Foley, S.F. Rejuvenation and erosion of the cratonic lithosphere. Nat. Geosci. 2008, 1, 503. [CrossRef]

93. Kelemen, P.B.; Hart, S.R.; Bernstein, S. Silica enrichment in the continental upper mantle via melt/rock reaction. Earth Planet. Sci. Lett. 1998, 164, 387-406. [CrossRef]

(C) 2019 by the authors. Licensee MDPI, Basel, Switzerland. This article is an open access article distributed under the terms and conditions of the Creative Commons Attribution (CC BY) license (http://creativecommons.org/licenses/by/4.0/). 